Bathymetrical Survey of the Fresh-Water Lochs of Scotland. Part XI. The Lochs of the Beauly Basin

Author(s): John Murray, Laurence Pullar, B. N. Peach and J. Horne

Source: The Geographical Journal, Vol. 27, No. 6 (Jun., 1906), pp. 566-585

Published by: geographicalj

Stable URL: http://www.jstor.org/stable/1776293

Accessed: 27-06-2016 08:45 UTC

Your use of the JSTOR archive indicates your acceptance of the Terms \& Conditions of Use, available at

http://about.jstor.org/terms

JSTOR is a not-for-profit service that helps scholars, researchers, and students discover, use, and build upon a wide range of content in a trusted digital archive. We use information technology and tools to increase productivity and facilitate new forms of scholarship. For more information about JSTOR, please contact support@jstor.org.

The Royal Geographical Society (with the Institute of British Geographers), Wiley are collaborating with JSTOR to digitize, preserve and extend access to The Geographical Journal 
necessary. Six men are, however, so engaged in the colonies at the present time, and it may be said that the economic survey of British West Africa is already well in hand. The Imperial Institute supplies the nucleus and permanent staff for dealing with the results of these surveys and this work, which can only be properly conducted in London. It remains to determine how the scheme of surveys is best arranged.

Through the Colonial Office as the controlling body, with the co-operation of the Royal Geographical Society, the London School of Tropical Medicine, and the Imperial Institute, an efficient plan of operations ought to be easy to arrange. But the ground to be covered is enormous, and, as Mr. Scott Elliot suggests, it will be prudent to take one country at a time. Personally, for many reasons, I should be inclined towards the selection of West Africa for the first action, and that because so much is already arranged on the proper lines for the initial development of that vast country.

[Prof. Wyndham Dunstan's support of my suggestions is extremely gratifying, and the Imperial Institute would be of an inestimable assistance to the survey. Yet I must protest strongly against his view that either the Colonial Office or the Imperial Institute could possibly conduct such a survey so well as the Royal Geographical Society. The Colonial Office has in the past, and will no doubt in the future, continue surveying and reporting, but no Government office could possibly undertake or control work of this nature. Otherwise such work would have been done long ago.-G. F. S. E.]

\section{BATHYMETRICAL SURVEY OF THE FRESH-WATER LOCHS OF SCOTLAND.*}

Under the Direction of Sir JOHN MURRAY, K.C.B., F.R.S., D.Sc., etc., and LAURENCE PULLAR, F.R.S.E.

\section{Part XI.-The Lochs of the Beauly Basin.}

The Beauly basin is an important and extensive one, extending across almost the entire width of Scotland, from Beauly firth on the east coast to within about 4 miles from the shores of Loch Duich, and about 6 miles from the shores of Loch Carron, on the west coast. The basin is situated in a very mountainous district, many of the peaks in the central and western part of the basin exceeding 3000 feet, and some of them approaching 4000 feet, in height, while on proceeding eastward towards the outlet of the basin the land becomes gradually less elevated. On the southern boundary of the basin are Tigh Mor (3222 feet), Sgùrr nan Conbhairean (3634 feet), Garbh Leac (3673 feet), Sgùrr nan Ceathramhan (3614 feet), Ciste Dhubh (3218 feet), Carn Fuaraloch (3241 feet), and Sgùrr a' Bhealaich Dheirg (3378 feet); on the western boundary Beinn Fhada (Ben Attow), 3383 feet, Sgùrr nan

\footnotetext{
* Plates, p. 656.
} 
Ceathreamhnan (3771 feet), Lurg Mhor (3234 feet), and Sgùrr Choinnich (3260 feet); on the northern boundary Sgùrr a' Chaoruinn (3452 feet), Bidean an Eoin Deirg (3430 feet), Maoile Lunndaidh (3294 feet), Sgùrr Fhuar-Thuill (3439 feet), Sgorr a' Choir-Ghlais (3552 feet), and Sgùrr Ruadh (3254 feet); while in the central part of the basin are Craig Dhubh (3102 feet), Sgùrr na Lapaich (3773 feet), An Riabhachan (3696 feet), Beinn Fhionnlaidh (3294 feet), Mam Sodhail (Mam Soul, 3862 feet), Carn Eige (3877 feet), Tom a' Choinich (3646 feet), a second peak named Sgùrr na Lapaich (3401 feet), and Tuill Creagach (3452 feet). Besides these heights there are many others which do

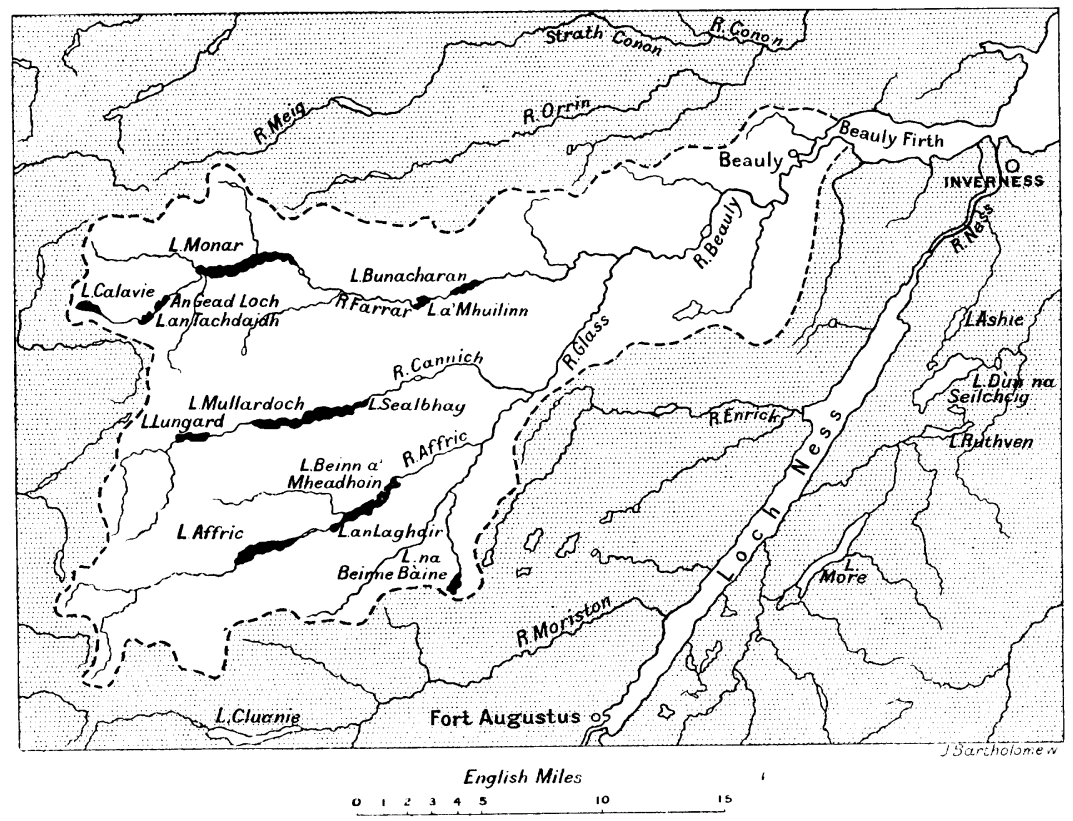

FIG. 1.-INDEX MAP OF THE BEAULY BASIN.

not attain the 3000 -feet level. In the valleys between these chains of mountains lie the lochs which were sounded by the Lake Survey staff. In the most northerly valley, Glen Strath Farrar, there is the connected series consisting of Lochs Calavie, an Tachdaidh, an Gead, Monar, a' Mhuilinn, and Bunacharan; in the central valley, Glen Cannicb, the connected series of Lochs Lungard, Mullardoch, and Sealbhag; and in the most southerly valley, Glen Affric, the connected series of Lochs Affric, an Laghair, and Beinn a' Mheadhoin; with the isolated Loch na Beinne Bàine as an outlier situated towards the head of Strath (t)lass. These valleys all trend in a more or less east-andwest direction, converging towards the north-east, where the river 
Beauly is formed by the junction of the river Farrar with the river Glass. The river Glass is formed by the junction of the Amhuinn Deabhaidh (bearing the outflow from Loch na Beinne Bàine) with the river Affric, while the river Cannich is a tributary of the river Glass. The river-systems within the Beauly basin, and the relative positions of the different lochs, are shown on the accompanying index-map (Fig. 1). The area of the entire basin, as measured with the planimeter on the 1-inch Ordnance Survey maps, is about 343 square miles, of which about 215 square miles (or 63 per cent.) drain into these thirteen lochs, as will be seen from the summary table at the end of this paper. An inspection of the summary table shows, further, that all the lochs exceed half a mile in length, while eight of them exceed a mile in length; the two largest lochs (Mullardoch and Monar) exceed 4 miles in length, and have each an area exceeding a square mile. Seven of the lochs exceed 100 feet in depth, and two of them exceed 200 feet, the deepest one being Loch Monar with a maximum depth of 260 feet; this loch is also the one containing the largest volume of water. The boundary-line between the counties of Inverness and Ross runs up the centre of Loch Monar for the greater part of its length, and it crosses Loch Mullardoch in its central portion, so that these two lochs lie partly in Ross-shire and partly in Inverness-shire; four of the others (Lochs Lungard, Calavie, an Tachdaidh, and an Gead) are situated in Ross-shire, and the remaining seven in Inverness-shire. The scenery of the district around the lochs is very fine, and the troutfishing in most of the lochs very good; some of them contain pike also.

Loch Affric (see Plate I.).-Loch Affric (or Affaric) lies about 26 miles to the south-west of Beauly, which is the nearest railway-station, and about 11 miles from Glen Affric Hotel at Cannich, the nearest house of entertainment. The loch trends in a west-south-west and east-north-easterly direction, and is nearly $3 \frac{1}{4}$ miles in length. It is broadest towards the western end, where the maximum breadth is nearly half a mile, narrowing gradually, though irregularly, on proceeding towards the eastern end, the mean breadth of the entire loch being a quarter of a mile. The superficial area is about 526 acres, or over four-fifths of a square mile, and the area drained by the loch is nearly 47 square miles. The maximum depth of 221 feet was observed near the centre of the loch. The volume of water is estimated at 2146 millions of cubic feet, and the mean depth at nearly 94 feet. The loch was surveyed on October 6 and 7, 1903, when the elevation of the lakesurface above the sea was determined by levelling from bench-mark as being $747 \cdot 0$ feet; when levelled by the officers of the Ordnance Survey on July 3, 1867, the elevation was found to be $\mathbf{7 4 4} \cdot 1$ feet above sealevel, or 3 feet lower than 1903.

Loch Affric is quite simple in conformation, the deeper water 
occupying a central position, from which the bottom slopes upward to the shores on all sides. The 50-feet contour coincides approximately with the outline of the loch, enclosing a hasin nearly $2 \frac{1}{2}$ miles in length, approaching comparatively close to the west end, but distant more than a quarter of a mile from the east end. Separated from this main 50feet basin by shallower water is an isolated sounding of 54 feet, near the east end where the main loch is joined ly the little subsidiary lasin called Loch Pollan Fearna, in which a maximum depth of 30 feet was observed. The 100-feet basin is $2 \frac{1}{4}$ miles in length, and the 150 -feet basin nearly $1 \frac{1}{2}$ miles in length, approaching in each case nearer to the west end than to the east end. The 200 -feet basin is about three-quarters of a mile in length, and is approximately equidistant from both ends of the loch, but the deepest sounding in 221 feet was taken towards the west end of the basin, and therefore nearer to the western end of the loch. A section along the centre of the loch from end to end is shown in the longitudinal section $\mathbf{A}-\mathbf{B}$ on the map, and a section across the loch in the position of the deepest sounding is shown in cross-section C-D. This last section shows a very slight irregularity in the deepest part of the loch, where a sounding in 209 feet was taken between a sounding in 211 feet on the one hand, and the greatest depth of the loch (221 feet) on the other. Another line of soundings, about threequarters of a mile further east, shows a shoaling in deep water, where a depth of 122 feet was recorded between a depth of 130 feet on one side, and 159 feet on the other. With these exceptions, the various lines of soundings show a regular bottom, with a steep off-shore slope in some places along hoth the northern and southern shores. Thus, proceeding along the northern shore from the east end of the loch, the first line of soundings gave a depth of 40 feet at a distance of 20 feet from shore; the fourth line of soundings gave a similar depth at a similar distance; the fifth line gave a depth of 28 feet at 10 feet from shore; the ninth line gave 47 feet at 30 feet; the next line gave 21 feet at a distance of 20 feet; the next line 84 feet at 60 feet distance ; the next 35 feet at 25 feet distance; and the next line 36 feet at 30 feet distance. In like manner proceeding along the southern shore from the east end, the sixth line of soundings gave a depth of 76 feet at a distance of 50 feet from shore; the next line gave 31 feet at 20 feet distance; the next line 47 feet at 15 feet distance; the next line 33 feet at 20 feet distance; and the next line 34 feet at 30 feet distance. All these figures indicate a slope exceeding 1 in 1 , and in one case a slope exceeding 3 in 1 . The following table gives the areas between the consecutive contour-lines at intervals of 50 feet, with the percentages to the total area of the loch, the flat-bottomed character of the basin being indicated by the larger zone on the deeper side of the 100 -feet contour than on the shallower side :- 


\begin{tabular}{|c|c|c|c|c|c|c|}
\hline $\begin{array}{l}\text { Feet. } \\
0 \text { to } 50\end{array}$ & . & 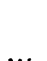 & . & $\begin{array}{c}\text { Acres. } \\
195 .\end{array}$ & 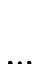 & er cent. \\
\hline 50,100 & $\ldots$ & $\ldots$ & $\cdots$ & 89 & $\ldots$ & 17 \\
\hline 100,150 & $\ldots$ & $\ldots$ & $\ldots$ & 125 & $\ldots$ & 24 \\
\hline 150,200 & $\ldots$ & $\ldots$ & $\ldots$ & 70 & $\ldots$ & 13 \\
\hline Over 200 & $\ldots$ & $\ldots$ & $\ldots$ & 47 & ... & 9 \\
\hline & & & & 526 & & 100 \\
\hline
\end{tabular}

Temperature Olservations.-A series of temperatures taken at 3 p.m. on October 6, 1903, in the deepest part of the loch, gave the following results :-

\begin{tabular}{|c|c|c|c|c|c|c|c|c|c|c|}
\hline Surf & & & $\cdots$ & & & $\cdots$ & $\cdots$ & $\ldots$ & $49^{\circ} \cdot 2$ & Tahr. \\
\hline 10 & eet & $\ldots$ & $\ldots$ & $\ldots$ & $\ldots$ & $\ldots$ & $\ldots$ & $\ldots$ & $48^{\circ} \cdot 9$ & , \\
\hline 25 & , & $\ldots$ & $\ldots$ & $\ldots$ & $\ldots$ & ... & $\ldots$ & $\ldots$ & $48^{\circ} \cdot 6$ & , \\
\hline 50 & , & $\ldots$ & $\ldots$ & ... & $\ldots$ & $\ldots$ & $\ldots$ & $\ldots$ & $48^{\circ} \cdot 0$ & $"$ \\
\hline 100 & , & $\ldots$ & $\ldots$ & $\ldots$ & $\ldots$ & $\ldots$ & $\ldots$ & $\ldots$ & $47^{\circ} \cdot 0$ & , \\
\hline 150 & , & $\ldots$ & $\ldots$ & $\ldots$ & $\ldots$ & $\ldots$ & $\ldots$ & $\ldots$ & $45^{\circ} \cdot 6$ & ", \\
\hline 200 & , & $\ldots$ & $\ldots$ & $\ldots$ & $\ldots$ & $\ldots$ & $\ldots$ & $\ldots$ & $44^{\circ} \cdot 8$ & , \\
\hline
\end{tabular}

The extreme range shown by these observations is only 4.4 from surface to bottom, the fall of temperature being very gradual.

Loch an Laghair (see Plate II.).-Loch an Laghair lies a little over a mile to the north-east of Loch Affric, and is practically continuous with Loch Beinn a' Mheadhoin, for normally the two lochs stand at the same level, although an easterly gale sets up a strong current through the narrows at Blàr an Ath, in which a depth of 5 feet was observed. The loch trends in a north-east and south-west direction, and is nearly two-thirds of a mile in length. The maximum width exceeds a quarter of a mile towards the western end, whence the loch narrows gradually towards the eastern end. The superficial area of the loch is about 83 acres, and the area draining directly into it nearly 6 square miles, but since it receires the overflow from Loch Affric its total drainage area is about $52 \frac{1}{2}$ square miles, an area over four hundred times greater than that of the loch. The deepest sounding in 100 feet was taken in the central part of the loch, but rather nearer to the north-east end. The volume of water is estimated at 135 million cubic feet, and the mean depth at $37 \frac{1}{4}$ feet. The loch was surveyed on October 6, 1903; but the elevation of the lake-surface above the sea could not be determined by levelling, as there was no bench-mark near the loch. The level was estimated at about 703 feet above sea-level.

Loch an Laghair forms a simple basin, the shallower contours coinciding approximately with the outline of the loch, but approaching closer to the northern shore in the eastern half of the loch, where the off-shore slope is steepest. The western end is apparently being silted up. The 75-feet area is extremely small, for on each side of the deepest sounding in 100 feet, at a distance represented by twenty strokes of the oar, the depths were 66 and 64 feet respectively. A section across the loch at the position of the deepest sounding is shown 
in cross-section E-F on the map, and a section along both Loch an Laghair and Loch Beinn a' Mheadhoin is shown in the longitudinal section A-B. The area of the lake-floor in Loch an Laghair covered by less than 50 feet of water is about 63 acres, or 76 per cent. of the total area of the loch. The temperature of the surface water at 3.30 p.m. on the date of the survey was $48^{\circ} \cdot 0 \mathrm{Fahr}$, the air-temperature leing $42^{\circ} \cdot 0$.

Loch Beinn a' Mheadhoin (see Plate II.).-Loch Beinn a' Mheadhoin (or Beinnavian or Beneveian) trends generally in a north-east and southwesterly direction, and is over $2 \frac{1}{2}$ miles in length. The loch is fairly uniform in width, the two end portions being somewhat narrower than the central portion, which has a maximum breadth of nearly half a mile, the mean breadth of the entire loch exceeding a quarter of a mile. The superficial area of the loch is about 504 acres, or over threequarters of a square mile, and the area of land draining directly into it is about $15 \frac{1}{2}$ square miles; but since it receives the superfluent waters from Lochs Affric and an Laghair, the total drainage area is about 68 square miles. The maximum depth of 167 feet was observed in a central position, but nearer to the eastern than to the western end of the loch. The volume of water is estimated at 1435 millions of cubic feet, and the mean depth at over 65 feet. "The loch was surveyed on October 6, 1903; but the elevation of the lake-surface above the sea could not be determined by levelling. The water in the loch was very high on the date of the survey, the level then being estimated at about 703 feet above sea-level, but the normal level is probably about 700 feet.

Loch Beinn a' Mheadhoin is rather complex in conformation, including as it does three deep basins separated by shallower water. Near the western end of the loch is a small basin having a maximum depth of 95 feet, and near the eastern end is a larger basin having a maximum depth of 117 feet, while the largest and deepest basin occupies the central portion. The two ridges separating these three basins may be due to the deposition of material brought down by the streams entering the loch at these places along the northern shore, of which the westerly stream (Amhainn a' Ghlinne Fhiadhaich) is the more important; the maximum depth observed on the western ridge was 69 feet, and on the eastern ridge 97 feet. The 25-feet and 50-feet contours are continuous from end to end of the loch, while the 75 -feet contour is broken at the position of the western ridge, and the 100 -feet contour is broken at the position of the eastern ridge. The eastern 100-feet kasin is nearly half a mile in length, and the main 100 -feet basin nearly $1 \frac{1}{2}$ miles in length; within the last-mentioned basin is a long narrow 150 -feet basin, based on soundings of 159,167 , and 154 feet, with an isolated sounding in 156 feet a quarter of a mile farther west. It 
seems doubtful whether this isolated sounding may not be connected with the principal kasin by deep water, and in that case the 150-feet basin would be nearly a mile in length. The deepest sounding in 167 feet was recorded about a mile from the eastern end of the loch, and about $1 \frac{1}{2}$ miles from the western end. The cross-section C-D, in this position, shows a steeper gradient off the northern than off the southern shore; but the soundings, as a whole, afford no evidence of any very steep slopes. The deeper part of the loch has quite a flat-bottomed character, as indicated by the figures in the following table, giving the areas between the consecutive contour-lines :-

\begin{tabular}{|c|c|c|c|c|c|c|}
\hline \multicolumn{3}{|l|}{ Feet. } & \multicolumn{3}{|c|}{ Acres. } & Per cent. \\
\hline 0 to 25 & ... & $\cdots$ & ... & 98 & ... & 19.5 \\
\hline 25 to 50 & $\ldots$ & $\ldots$ & $\ldots$ & 80 & $\ldots$ & $15 \cdot 8$ \\
\hline 50 to 75 & ... & $\ldots$ & ... & 96 & $\ldots$ & $19 \cdot 0$ \\
\hline 75 to 100 & $\ldots$ & $\ldots$ & $\ldots$ & 174 & $\ldots$ & $34 \cdot 5$ \\
\hline Over 100 & ... & ... & ... & 56 & $\ldots$ & $11 \cdot 2$ \\
\hline & & & & 504 & & $100 \cdot 0$ \\
\hline
\end{tabular}

It will be observed that the largest zone is the one between 75 and 100 feet, and that the area of the lake-floor covered by less than 50 feet of water is about 178 acres, as compared with 270 acres covered by water between 50 and 100 feet in depth, or 35 per cent. as compared with 53 per cent. In most lakes the arrangement is the reverse of this, the areas between consecutive contour-lines drawn at equal intervals, usually decreasing with increase of depth. The temperature of the surface water at the east end on commencing the survey was $50^{\circ} .0 \mathrm{Fahr}$., the temperature of the air being $42^{\circ} .5$, while later in the afternoon, towards the opposite end the surface temperature was $49^{\circ} .5$; but, an easterly gale having sprung up, it was found impossible to take serial temperatures beneath the surface.

Loch na Beinne Bàine (see Plate V.).- Loch na Beinne Bàine lies in Guisachan forest, about 4 miles to the south-east of Loch Beinn a' Mheadhoin, and 8 or 9 miles to the west of Invermoriston on Loch Ness. It is irregular in outline, trends in a north-north-east and south-south-westerly direction, and is nearly a mile in length, with a maximum breadth of nearly half a mile. The superficial area is about 154 acres, or a quarter of a square mile, and the area draining into it about $1 \frac{1}{2}$ square miles. The maximum depth of 67 feet was observed about a quarter of a mile from the southern end of the loch, midway between an island of stones and the eastern shore. The volume of water is estimated at 190 million cubic feet, and the mean depth at $28 \frac{1}{3}$ feet. The loch was surveyed on June 6,1904 , but the elevation of the lake-surface above the sea could not be determined; the height of the water at the sluice was about 2 feet, and at one time the loch appears to have been considerably higher. 
Loch na Beinne Bàine forms a simple basin; the 25-feet contour coincides approximately with the outline of the loch, but is deflected at the position of the island of stones off the western shore towards the southern end, while the 50 -feet basin, based on soundings of $67,64,54$, and 52 feet, is contained in the southern half of the loch, and is about a quarter of a mile in length. The soundings indicate in one or two places slight undulations of the lake-floor, but as a rule the slope of the bottom is regular and gentle. The area covered by less than 25 feet of water is about 95 acres, or 62 per cent. of the total area.

Temperature Observations. - A series of temperatures taken in the deepest part of the loch gave the following results :-

\begin{tabular}{|c|c|c|c|c|c|c|c|c|c|c|}
\hline \multirow{2}{*}{\multicolumn{2}{|c|}{$\begin{array}{l}\text { Surface } \\
10 \text { feet }\end{array}$}} & & $\cdots$ & $\ldots$ & $\cdots$ & $\ldots$ & & $\ldots$ & \multicolumn{2}{|c|}{$60^{\circ} \cdot 8 \mathrm{Fahr}$} \\
\hline & & $\ldots$ & $\ldots$ & $\ldots$ & $\ldots$ & $\ldots$ & $\ldots$ & $\ldots$ & $60^{\circ} \cdot 0$ & \\
\hline 20 & $"$ & $\ldots$ & $\ldots$ & $\ldots$ & $\ldots$ & $\ldots$ & $\ldots$ & $\ldots$ & $50^{\circ} \cdot 5$ & " \\
\hline 40 & " & $\ldots$ & $\ldots$ & $\ldots$ & $\ldots$ & $\ldots$ & $\ldots$ & $\ldots$ & $47^{\circ} \cdot 6$ & " \\
\hline 60 & " & $\ldots$ & $\ldots$ & $\ldots$ & $\ldots$ & $\ldots$ & $\ldots$ & $\ldots$ & $46^{\circ} 5$ & " \\
\hline
\end{tabular}

These observations indicate an extreme range of temperature from surface to bottom amounting to $14^{\circ} \cdot 3$, there being a fall of $9^{\circ} \cdot 5$ between 10 and 20 feet, which is nearly equal to a fall in temperature of one degree per foot of depth. Reference has elsewhere been made to the large range and rapid fall of temperature observed in Lochs Monzievaird, Achilty, and Dubh, ${ }^{*}$ and the temperatures here given from Loch na Beinne Bàine afford another instance for comparison.

Loch Lungard (see Plate V.).-Loch Lungard (or Longart, or Glasletter) lies at the head of Glen Cannich, about 5 miles to the north of Loch Affric. It trends east and west, and is $1 \frac{1}{2}$ miles in length, with a maximum breadth towards the west end of one-third of a mile, whence the loch narrows gradually towards the east. The superficial area is about 216 acres, or one-third of a square mile, and the area draining into it is nearly 23 square miles. The maximum depth of 129 feet was observed in a central position, but towards the east end. The volume of water is estimated at 599 million cubic feet, and the mean depth at nearly 64 feet. The loch was surveyed on October 7, 1903, when the elevation of the lake-surface above the sea was found by levelling from bench-mark to be 761.3 feet, which is nearly identical with the level observed by the Ordnance Survey officers on October 14, 1867, viz. 761.2 feet. When surveyed the water was about its normal level, and in floods might rise about 3 feet.

Loch Lungard is extremely simple in conformation, the bottom sloping down on all sides towards the deepest part, not the slightest irregularity being indicated by the soundings, while the contour-lines coincide approximately with the outline of the loch. This is shown in

* See Geogr. Joui'n., vol. 26, pp. 55, 56, July, 1905. 
both the longitudinal section A-B and the cross-section C-D on the map. The 50-feet basin is $1 \frac{1}{4}$ miles, and the 100 -feet basin rather under a mile, in length, and they are comparatively wide, so that the loch is of a flat-bottomed character, as is shown by the following table, giving the areas and percentages between the contour-lines :-

$\begin{array}{ccccccc}\text { Feet. } & & & & \text { Acres. } & & \text { Per cent. } \\ 0 \text { to } 50 & \ldots & \ldots & \ldots & 87 & \ldots & 40 \\ 50 \# 100 & \ldots & \ldots & \ldots & 81 & \ldots & 38 \\ \text { Over 100 } & \ldots & \ldots & \ldots & 48 & \ldots & 22 \\ & & & & \frac{216}{216} & & \frac{100}{100}\end{array}$

Temperature Observations.-The following series of temperatures, taken at 2 p.m. on the date of the survey in the deepest part of the loch, indicates a range of only $1^{\circ} \cdot 2$ Fabr. throughout the body of water :-

\begin{tabular}{|c|c|c|c|c|c|c|c|c|}
\hline Surface & ... & $\ldots$ & ... & $\cdots$ & $\cdots$ & $\ldots$ & $\ldots$ & $49^{\circ} \cdot 2 \mathrm{Fahr}$ \\
\hline 25 feet & ... & $\ldots$ & $\ldots$ & $\ldots$ & $\ldots$ & $\ldots$ & $\ldots$ & $49^{\circ} \cdot 0 \quad$, \\
\hline 50, & $\ldots$ & $\ldots$ & $\ldots$ & $\ldots$ & $\ldots$ & $\ldots$ & $\ldots$ & $48^{\circ} \cdot 8$ \\
\hline 125 & $\ldots$ & $\ldots$ & $\ldots$ & $\ldots$ & $\ldots$ & $\ldots$ & $\ldots$ & $48^{\circ} \cdot 0$ \\
\hline
\end{tabular}

Loch Mullardoch (see Plate III.).-Loch Mullardoch (or Mulardich, or Moyley) lies less than 2 miles to the east of Loch Lungard, and is practically continuous with Loch Sealbhag, there being a small expansion of the river between them called Loch Ath a' Bhàn, which was not sounded. Loch Mullardoch trends generally in an east and westerly direction, and is somewhat irregular in outline, with a slight bend in the central portion. It exceeds 4 miles in length, and is pretty uniform in width, the maximum breadth being less than half a mile, and the mean breadth over a quarter of a mile. Its waters cover an area of about 756 acres, or considerably more than a square mile, and the area draining directly into it is about $27 \frac{1}{2}$ square miles; but since it receives the outflow from Loch Lungard its total drainage area exceeds 50 square miles. The maximum depth of 197 feet was observed in the eastern portion of the loch, about a mile and a half from the east end. The volume of water is estimated at 2553 millions of cubic feet, and the mean depth at $77 \frac{1}{2}$ feet. The loch was surveyed on October 7,1903 , but the elevation above the sea was not determined; when levelled by the Ordnance Survey officers on November 29, 1866, the elevation of the lake-surface was found to be 704.9 feet above sea-level. On the date of the survey the water was about a foot above the normal level, and two days previously it had been 3 feet higher.

Loch Mullardoch is divided into two deep basins by a shoaling of the water in its central portion, where there is a constriction and bend in the outline, the maximum depth in the western basin being 150 feet, and in the eastern basin 197 feet, the depth on the shoaling being 80 feet. A section across the deepest part of the western basin is shown in 
cross-section C-D, and one across the deepest part of the eastern basin in cross-section $\mathbf{E}-\mathbf{F}$, on the map, and a section along the centre of the loch from end to end is shown in the longitudinal section $A-B$ at the foot of the map. This last-mentioned section brings out the central shoaling referred to, which is apparently traceable to the influence of the streams entering on both sides of the loch at this place, and principally of the Allt Taige, at the mouth of which, on the northern shore, is a considerable delta. The 50 -feet contour is continuous, and encloses a basin nearly 4 miles in length. The western 100-feet basin exceeds half a mile in length, separated by an interval of over half a mile from the eastern $\mathbf{1 0 0}$-feet basin, which is one and a half miles in length, and includes a 150-feet basin over a mile in length. All the cross-lines of soundings show a regular bottom, the water deepening gradually from the shore towards the centre, with a steep off-shore slope in some places, as, for instance, along the southern shore off Creag Dubh, where a sounding in 24 feet was taken about 20 feet from shore, and off Creag a' Bhaca, at the deepest part of the loch, where a sounding in 94 feet was taken about 100 feet from shore. The following table gives the approximate areas between the consecutive contour-lines at intervals of 50 feet, and the percentages to the total area of the loch, and indicates the flat-bottomed character of the basin, the comparatively large area of the lake-floor covered by more than 150 feet of water being noteworthy :-

\begin{tabular}{|c|c|c|c|c|c|c|}
\hline \multicolumn{4}{|l|}{ Feet. } & \multicolumn{2}{|l|}{ Acres. } & \multirow{2}{*}{$\begin{array}{l}\text { P'er cent. } \\
\quad 39\end{array}$} \\
\hline 0 to 50 & ... & $\cdots$ & & 298 & ... & \\
\hline 50,100 & $\ldots$ & $\ldots$ & $\ldots$ & 228 & ... & 30 \\
\hline 100,150 & $\ldots$ & $\ldots$ & $\ldots$ & 121 & $\ldots$ & 16 \\
\hline Over 150 & ... & ... & ... & 109 & $\ldots$ & 15 \\
\hline & & & & 756 & & 100 \\
\hline
\end{tabular}

Temperature Observations.-The following series of temperatures, taken at 4.30 p.m. on the date of the survey in the western basin, shows that the water was nearly uniform in temperature, the extreme range from surface to bottom being only $1^{\circ}$ Fahr., the readings down to a depth of 50 feet being identical :-

\begin{tabular}{|c|c|c|c|c|c|c|c|c|c|}
\hline Surface & $\ldots$ & ... & $\cdots$ & $\ldots$ & $\ldots$ & $\cdots$ & $\ldots$ & $50^{\circ} \cdot 0$ & Fabr \\
\hline 10 feet & $\ldots$ & $\ldots$ & $\ldots$ & $\ldots$ & $\ldots$ & $\ldots$ & $\ldots$ & $50^{\circ} \cdot 0$ & \\
\hline 25, & $\ldots$ & $\ldots$ & $\ldots$ & $\ldots$ & $\ldots$ & $\ldots$ & $\ldots$ & $50^{\circ} \cdot 0$ & , \\
\hline 50 & $\ldots$ & $\ldots$ & $\ldots$ & $\ldots$ & $\ldots$ & ... & $\ldots$ & $50^{\circ} \cdot 0$ & 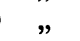 \\
\hline 100 & $\ldots$ & $\ldots$ & $\ldots$ & $\ldots$ & $\ldots$ & $\ldots$ & $\ldots$ & $49^{\circ} \cdot 5$ & , \\
\hline 150 , & $\ldots$ & $\ldots$ & $\ldots$ & $\ldots$ & $\ldots$ & $\ldots$ & $\ldots$ & $49^{\circ} \cdot 0$ & " \\
\hline
\end{tabular}

Loch Sealbhag (see Plate III.).-Loch Sealbhag lies to the east of, and is, as already stated, practically a continuation of Loch Mullardoch. It trends in a north-east and south-westerly direction, and is two thirds of a mile in length, with a maximum breadth towards the west end of nearly a quarter of a mile, whence it narrows gradually towards the 
north-east. Its waters cover an area of about 68 acres, and it drains directly an area of $3 \frac{1}{2}$ square miles, but since it receives the outflow from Lochs Lungard and Mullardoch, its total drainage area is nearly 54 square miles-an area nearly five hundred times greater than that of the loch. The maximum depth of 56 feet was observed in the widest part of the loch towards the western end, and comparatively near the southern shore. The volume of water is estimated at 61 million cubic feet, and the mean depth at over $20 \frac{1}{2}$ feet. The loch was surveyed on October 5,1903 , but the elevation above the sea could not be determined.

The wide western portion of Loch Sealbhag includes a deep basin exceeding 30 feet in depth, which approaches comparatively close to the western end, and is over a quarter of a mile in length. To the northeast of this basin the bottom rises, and falls again on approaching the outfall to a depth of 31 feet, the depth on the rise being 16 feet. The area of the lake-floor covered by less than 20 feet of water is about 39 acres, or 57 per cent. of the total area. The temperature of the surface water on the date of the survey was $50^{\circ} \cdot 5 \mathrm{Fahr}$.

Loch Calavie (see Plate V.).-Loch Calavie (or Calvie) lies about 6 miles to the north-west of Loch Lungard, and only 7 miles from the head of Loch Carron on the west coast of Scotland, at a high elevation among the mountains, the lower slopes of which are covered with peat. The loch trends in a north-west and south-easterly direction, and is considerably over a mile in length, with a maximum width towards the western end exceeding one-third of a mile, whence the breadth gradually decreases on approaching the eastern end. The superficial area is about 167 acres, or a quarter of a square mile, and the area draining into it nearly $2 \frac{1}{2}$ square miles. The maximum depth of 84 feet was observed in a central position, but rather nearer the western than the eastern end. The volume of water is estimated at 276 million cubic feet, and the mean depth at 38 feet. The loch was surveyed on October 19, 1904, when the elevation was found by levelling from bench-mark to be 1128.35 feet above the sea-a little lower than the elevation as determined by the Ordnance Survey officers on August 14, 1866, viz. 1128.5 feet above sea-level.

Loch Calavie is perfectly simple in conformation, the contour-lines coinciding approximately with the shore-line, though in each case they approach nearer to the western than to the eastern end of the loch, so that the average slope is steeper towards the head of the loch. This is shown in the longitudinal section $A-B$ on the map. The 25-feet basin is nearly a mile, and the 50-feet basin three-quarters of a mile, in length. The soundings give no indication of any steep off-shore slopes, and the average slope between the 25 -feet and 50-feet contours 
is less steep than in shallower water, as indicated in the following table by the larger area beyond the 25 -feet line :-

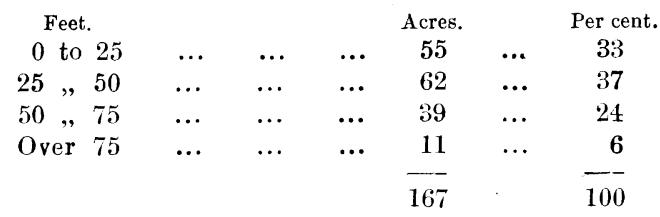

Temperature Observations.-The following series of temperatures taken in the deepest part of the loch shows that on the date of the survey the whole body of water was practically uniform in temperature, the extreme range heing less than $1^{\circ}$ Fahr. :-

$\begin{array}{cccccccccc}\text { Surface } & \ldots & \ldots & \ldots & \ldots & \ldots & \ldots & \ldots & 47^{\circ} \cdot 0 & \text { Fahr. } \\ 40 \text { feet } & \ldots & \ldots & \ldots & \ldots & \ldots & \ldots & \ldots & 46^{\circ} \cdot 3 & , \\ 75, & \ldots & \ldots & \ldots & \ldots & \ldots & \ldots & \ldots & 46^{\circ} \cdot 2 & \end{array}$

Loch an Tachdaidh (see Plate V.).-Loch an Tachdaidh lies about 2 miles to the east of Loch Calavie, and is almost continuous with Loch an Gead, the stream between them being a very short one, and the difference in level only $1 \frac{1}{2}$ feet. The term Gedd Lochs is applied to the connected series, consisting of Loch an Gead, Loch an Tachdaidh, and the neighbouring little Loch an Gobhlach, which was not sounded. Loch an Tachdaidh is irregular in outline, trends in a north-east and south-westerly direction, and is nearly two-thirds of a mile in length, with a maximum breadth exceeding one-third of a mile. Its waters cover an area of about 92 acres, and it drains directly an area exceeding 4 square miles, but since it receives the overflow from Loch Calavie, its total drainage area is over $6 \frac{1}{2}$ square miles. The maximum depth of 62 feet was observed in the centre of the north-eastern portion of the loch, near a heap of stones, showing above the surface of the water. The volume of water is estimated at 72 million cubic feet, and the mean depth at 18 feet. The loch was surveyed on October 21, 1904; the elevation could not be determined by levelling, but was estimated at about 831.5 feet above the sea.

Loch an Tachdaidh is irregular in conformation as well as in outline, and, besides the island of stones already mentioned, includes four small unnamed islands, the largest of which occupies a central position; the south-western portion is shallow and filled with weeds. The contour-lines are sinuous in character, the deepest part lying between the largest island and the heap of stones, where three soundings exceeding 50 feet in depth were taken. To the south of the largest island, and towards the eastern shore, a sounding in 25 feet was recorded, surrounded by shallower water. The area of the lake-floor covered by less than 25 feet of water is about 74 acres, or 81 per cent. of the total area. The following series of temperatures taken in the position of

No. VI.-June, 1906.]

$2 \mathrm{R}$ 
the deepest sounding shows a range of only $1^{\circ} \cdot 2$ Fahr. throughout the body of water, the deeper layers being uniform in temperature:-

\begin{tabular}{|c|c|c|c|c|c|c|c|c|}
\hline Surface & & $\ldots$ & & $\cdots$ & $\ldots$ & $\ldots$ & & $46^{\circ} \cdot 2 \mathrm{Fahr}$ \\
\hline 30 feet & $\ldots$ & $\cdots$ & $\ldots$ & ... & $\ldots$ & $\ldots$ & $\ldots$ & $45^{\circ} \cdot 0$ \\
\hline $60 \quad$ & ... & $\ldots$ & $\ldots$ & $\ldots$ & $\ldots$ & ... & $\ldots$ & $45^{\circ} \cdot 0$ \\
\hline
\end{tabular}

An Gead Loch (see Plate V.).-An Gead loch lies to the north-east of Loch an Tachdaidh, and trends in a similar direction, but is more regular in outline and more uniform in width. An Gead loch is nearly $1 \frac{1}{4}$ miles in length, with a maximum width towards the south-west end of a quarter of a mile. The superficial area is about 110 acres, and the area draining directly into it is about $2 \frac{1}{2}$ square miles, but since it receives the outflow from Lochs Calavie and an Tachdaidh, the total drainage area exceeds 9 square miles. The maximum depth of 30 feet was observed towards the north-eastern end of the loch. The volume of water is estimated at 54 million cubic feet, and the mean depth at $11 \frac{1}{4}$ feet. The loch was surveyed on October 21, 1904, and the elevation was estimated at about 830 feet above sea-level. The bottom of an Gead loch is irregular and stony, so much so that in the deeper part no mud could be got, while the shallow western portion is covered with sand. Though irregular, the basin has a flat-bottomed character, for the majority of the soundings were taken in depths exceeding 10 feet, and only three soundings in depths exceeding 20 feet. The area of the lake-floor covered by more than 10 feet of water is about 62 acres, or 56 per cent. of the total area. The temperature of the water was nearly uniform on the date of the survey, a reading at the surface giving $46^{\circ} \cdot 7 \mathrm{Fahr}$, and a reading at 25 feet $46^{\circ} \cdot 0$.

Loch Monar (see Plate IV.).-Loch Monar lies at the head of Glen Strath Farrar, little more than a mile to the north-east of an Gead loch, and is one of the most important lochs in the Beauly basin. In length and in superficial area it is slightly inferior to Loch Mullardoch, but it is the deepest of the series, and contains the largest volume of water. The general trend of Loch Monar is east and west, but with a slight sinuosity in the outline, the length exceeding 4 miles. The width varies considerably, the maximum breadth of nearly half a mile occurring near the west end, the mean breadth of the entire loch exceeding a quarter of a mile. The waters of the loch cover an area of about 750 acres, or over one square mile, and the area draining directly into it is about 41 square miles, but since it receives the overflow from Lochs Calavie, an Tachdaidh, and an Gead, the total drainage area is about 50 square miles. The maximum depth of 260 feet was observed much nearer the eastern than the western end. The volume of water is estimated at 3213 millions of cubic feet, and the mean depth at $98 \frac{1}{3}$ feet. The loch was surveyed on October 10 , 1903, when the elevation of the lake-surface above the sea was found 
to be 663.9 feet; when levelled by the officers of the Ordnance Survey on June 20,1866 , the elevation was 662.8 feet above sea-level. At the time of the survey the water was about its normal level, and might rise to the extent of several feet.

Loch Monar is quite simple in conformation, all the contour-lines enclosing continuous areas, and the cross-lines of soundings indicating a regularly sloping bottom from the shores out towards the centre of the loch. The longitudinal section, A-B on the map, along the centre of the loch from end to end shows slight undulations of the lake-floor, the shallowings coinciding with constrictions in the ontline. The contour-lines all approach nearer to the eastern than to the western end of the loch, showing a steeper slope in an easterly direction from the deepest sounding, which was taken less than a mile from the east end, or one-fourth of the distance from one end to the other. The offshore slope is in places very steep, especially along the southern shore at the deepest part of the loch, where near the centre of the loch a sounding in 104 feet was taken about 120 feet from shore; a little farther east another sounding in 50 feet was taken about 50 feet from shore; still farther east a sounding in 148 feet was taken about 120 feet from shore; and still farther east a sounding in 87 feet about 60 feet from shore. The last-mentioned sounding, which gives a slope of 29 in 20, was taken on the cross-line immediately to the east of the deepest sounding, and the steepest gradient observed off the northern shore was at the opposite end of the same line, where a sounding in 54 feet was taken at about 60 feet from shore. The crosssection C-D on the map is taken at the position of the deepest sounding, and shows a gentle off-shore slope, succeeded by a steeper slope on proceeding into deep water, the deeper part of the loch being of a flat-bottomed character. The area enclosed by the 50 -feet contour is nearly $3 \frac{1}{2}$ miles in length, being distant from the west end nearly threequarters of a mile, and extending into the narrow part at the east end off Creag Ghràda ; in the expansion of the out-flowing river, opposite Creag Dhubh, a depth of 64 feet was observed. The 100-feet basin is 3 miles, the 150 -feet basin $2 \frac{1}{2}$ miles, and the 200 -feet basin over one mile, in length. The approximate areas between the consecutive contour-lines drawn in at equal intervals, and the percentages to the total area of the loch, are given in the following table, from which it will be noticed that the area of the zone between 150 and 200 feet is larger than that of the two preceding shallower zones :-

$\begin{array}{rlllrlc}\text { Feet. } & & & & \text { Acres. } & & \text { Per cent. } \\ 0 \text { to } 50 & \ldots & \ldots & \ldots & 293 & \ldots & 39 \\ 50,100 & \ldots & \ldots & \ldots & 134 & \ldots & 18 \\ 100,150 & \ldots & \ldots & \ldots & 99 & \ldots & 13 \\ 150,200 & \ldots & \ldots & \ldots & 138 & \ldots & 18 \\ \text { Over } 200 & \ldots & \ldots & \ldots & 86 & \ldots & 12 \\ & & & & \overline{750} & & \overline{100}\end{array}$


Temperature Observations.-The following series of temperatures, taken in the deepest part of the loch at $4 \mathrm{p} . \mathrm{m}$. on the date of the survey, shows that the whole body of water varied little in temperature, being, in fact, uniform in temperature down to 100 feet, the extreme range amounting to only $1^{\circ .2}$ Fahr. :-

\begin{tabular}{|c|c|c|c|c|c|c|c|c|c|c|}
\hline Sur & & $\cdots$ & . & $\cdots$ & $\cdots$ & $\cdots$ & $\cdots$ & $\ldots$ & $49^{\circ} \cdot 5$ & Fahr \\
\hline 10 & ieet & $\ldots$ & $\ldots$ & $\ldots$ & $\ldots$ & $\ldots$ & $\ldots$ & $\ldots$ & $49^{\circ} 5$ & , \\
\hline 25 & ", & $\ldots$ & $\ldots$ & ... & $\ldots$ & $\ldots$ & $\ldots$ & $\ldots$ & $49^{\circ} \cdot 5$ & $"$ \\
\hline 50 & , & $\ldots$ & $\cdots$ & $\ldots$ & $\ldots$ & $\ldots$ & $\ldots$ & $\ldots$ & $49^{\circ} 5$ & $"$ \\
\hline 100 & . & $\cdots$ & $\cdots$ & $\ldots$ & $\ldots$ & $\ldots$ & $\ldots$ & $\ldots$ & $49^{\circ} \cdot 4$ & , \\
\hline 150 & . & $\ldots$ & $\ldots$ & $\ldots$ & $\ldots$ & $\cdots$ & $\ldots$ & $\cdots$ & $49^{\circ} \cdot 0$ & ," \\
\hline 170 & " & $\cdots$ & $\cdots$ & $\ldots$ & $\cdots$ & $\cdots$ & $\cdots$ & $\cdots$ & $48^{\circ} \cdot 5$ & \\
\hline 200 & " & $\cdots$ & $\ldots$ & $\ldots$ & $\ldots$ & $\ldots$ & $\ldots$ & $\ldots$ & $48^{\circ}: ?$ & \\
\hline
\end{tabular}

Loch a' Mhuilinn (see Plate V.).-Loch a' Mhuilinn (or Moilie) is a small irregular loch lying about 5 miles to the east of Loch Monar. A terrace of gravel surrounds the loch, except on the northern shore, where the hill An Carnach rises steeply from the lake-shore. There is a large island named Eilean a' Mhuilinn near the east end, and two smaller islands at the mouth of the inflowing river at the west end. The loch trends in an east-north-east and west-south-westerly direction, and is nearly a mile in length, with a maximum breadth in the centre exceeding one-third of a mile, whence it narrows towards the two ends. The superficial area is about 100 acres, and the area of land draining directly into it is about $37 \frac{3}{4}$ square miles, but since it receives the overflow from Lochs Monar, an Gead, an Tachdaidh, and Calavie, its total drainage area is nearly 88 square miles-an area 550 times greater than that of the loch. The maximum depth of 94 feet was observed in the wide part of the loch towards the northern shore. The volume of water is estimated at 150 million cubic feet, and the mean depth at over 34 feet. The loch was surveyed on October 12, 1903, when the elevation was determined by levelling from bench-mark as being $417 \cdot 65$ feet above the sea; when visited by the Ordnance Survey officers on June 1, 1866, the elevation was found to be 417.5 feet above sealevel. A drift-mark was observed 5 feet above the surface of the water on the date of the survey, when the level was about its normal.

Loch a' Mhuilinn consists of a deep central basin, with two small subsidiary shallow basins at the two ends, as shown in the longitudinal section on the map. Towards the west end, immediately to the north of the island at the mouth of the inflowing river, a depth of 25 feet was recorded, separated from the main basin by a rise of the bottom, on which a maximum depth of 12 feet was observed. Towards the east end, between Eilean a' Mhuilinn and the month of the outflowing river, a depth of 24 feet was recorded, separated from the main basin by a depth of 3 feet in the narrows between the island and the northern shore. In the main deep basin the contour-lines are continuous and 
the bottom regular, seven soundings in depths exceeding 80 feet having been recorded to the west and south-west of Eilean a' Mhuilinn, two of them in depths exceeding 90 feet. The area of the lake-floor covered by less than 50 feet of water is about 72 acres. The following series of temperatures taken in the deepest part of the loch shows that the body of water was nearly uniform in temperature on the date of the survey, the extreme range observed being less than $1^{\circ}$ Fahr. :-

\begin{tabular}{|c|c|c|c|c|c|c|c|c|c|}
\hline Surfac & $\ldots$ & $\ldots$ & $\ldots$ & $\cdots$ & $\cdots$ & $\ldots$ & $\ldots$ & \multicolumn{2}{|c|}{$47^{\circ} \cdot 2$ Fahr. } \\
\hline 10 feet & $\ldots$ & $\ldots$ & $\cdots$ & $\ldots$ & $\ldots$ & $\ldots$ & $\ldots$ & $47^{\circ} \cdot 0$ & ” \\
\hline $25 \quad$, & $\ldots$ & ... & $\cdots$ & ... & $\ldots$ & $\ldots$ & $\ldots$ & $46^{\circ} \cdot 8$ & " \\
\hline 50 & ... & $\cdots$ & $\cdots$ & $\ldots$ & ... & $\ldots$ & $\ldots$ & $46^{\circ} \cdot 6$ & ", \\
\hline 90 & & & $\ldots$ & $\ldots$ & $\ldots$ & $\ldots$ & $\ldots$ & $46^{\circ} \cdot 4$ & , \\
\hline
\end{tabular}

Loch Bunacharan (see Plate V.).-Loch Bunacharan (or Banchron) lies less than a mile to the east of Loch a' Mhuilinn and about 6 miles east of Loch Monar, and is the final one of the series of lochs in Glen Strath Farrar. The shores are mostly of gravelly débris, forming terraces about 20 feet high, which are best seen along the south shore; the surrounding hills are high and rugged, and well wooded. The loch trends east-north-east and west-south-west, and is $1 \frac{1}{4}$ miles in length, with a maximum width of nearly one-third of a mile, the superficial area being about 157 acres, or a quarter of a square mile. The area draining directly into Loch Bunacharan is only about 4 square miles, but it receives the overflow from Lochs Calavie, an Tachdaidh, an Gead, Monar, and a' Mhuilinn, and its total drainage area is therefore a very large one-about 92 square miles. The maximum depth of 113 feet was observed towards the east end of the loch-less than half a mile from the east end and more than three-quarters of a mile from the west end. The volume of water is estimated at about 343 million cubic feet, and the mean depth at over 50 feet. The loch was surveyed on October 12, 1903, when the elevation of the lake-surface above the sea was found by levelling from bench-mark to be $366 \cdot 15$ feet; when levelled by the officers of the Ordnance Survey on June 9, 1866, the elevation was 366.5 feet above sea-level. On the date of the survey the water was about its normal level, and a recent drift-mark was observed 9 feet above the surface of the water, while an older drift-mark was 11 feet above the water-surface.

Loch Bunacharan is irregular in conformation, the lake-floor in the deeper part of the loch rising and falling in a series of undulations. The 25-feet and 50-feet contours are continuous from end to end of the loch, and coincide approximately with the shore-line. The 75-feet contour, however, encloses three distinct basins separated from each other by shallower water, viz. (1) a very small basin based on a sounding in 83 feet about 300 yards from the western end; (2) a larger basin a quarter of a mile in length, and trending almost north and south, i.e. transversely across the loch, based on soundings in 78,82 . 


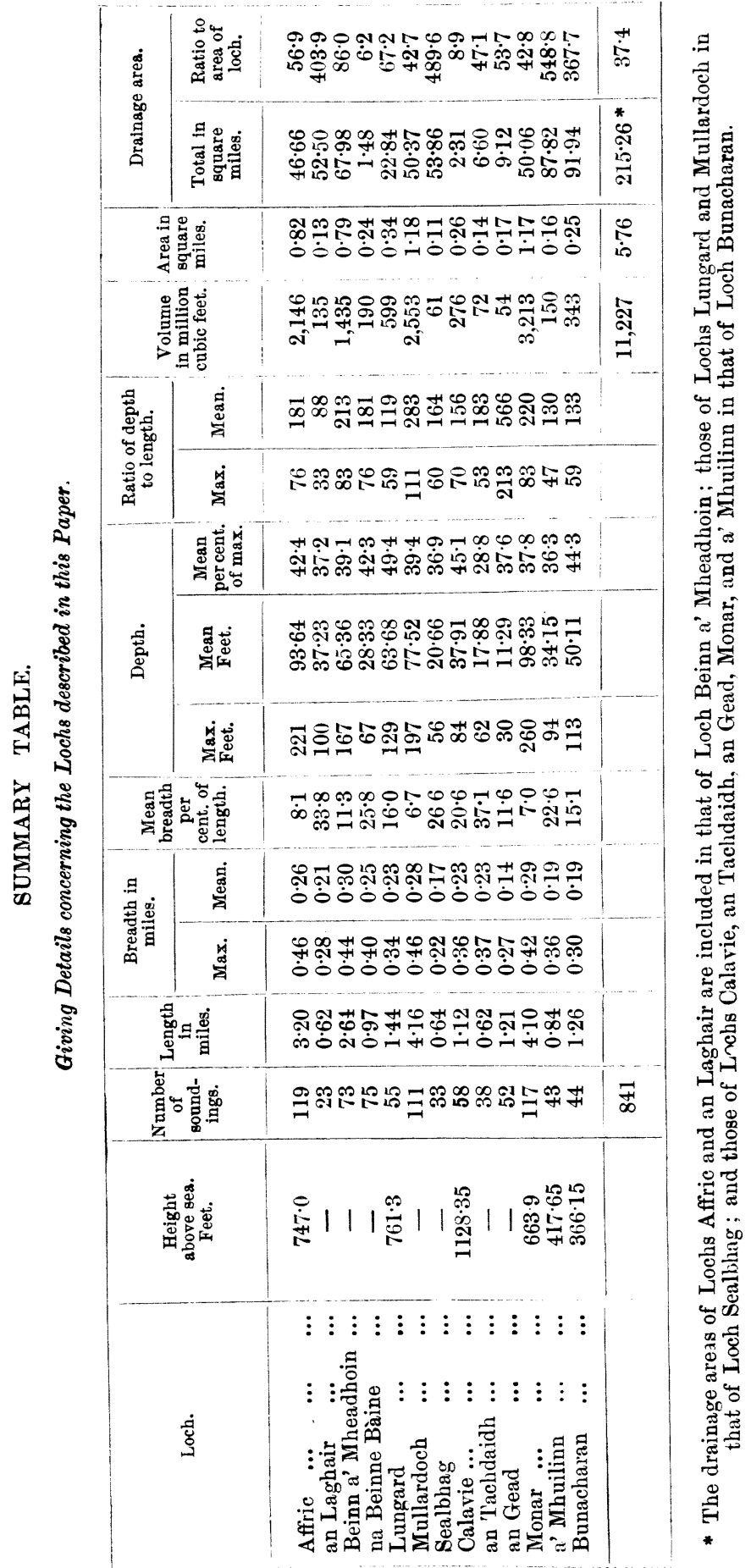


and 88 feet, situated about one-third of a mile from the western end; and (3) the largest and deepest basin, one-third of a mile in length, approaching to within a quarter of a mile from the eastern end, and enclosing a small basin exceeding 100 feet in depth, based on soundings in 105, 111, and 113 feet. Between the second and third basins above noted there is a rise of the lake-floor near the middle of the loch, covered by 43 feet of water, surrounded on all sides by deeper water. These inequalities are indicated to some extent in the longitudinal section $A-B$ on the map, taken along the axis of maximum depth, but most of the cross-lines of soundings show a regular bottom, as shown in cross-section $\mathrm{C}-\mathrm{D}$, taken at the position of the deepest sounding. The slope of the bottom seems to be gentle on the whole, the steepest gradient observed being off the northern shore towards the west end, where a sounding in 48 feet was taken about 50 feet from shore. The area of the lake-floor covered by less than 50 feet of water is about 80 acres, or 51 per cent. of the total area. The following series of temperatures, taken in the deepest part of the loch, show that the whole body of water was practically uniform in temperature :-

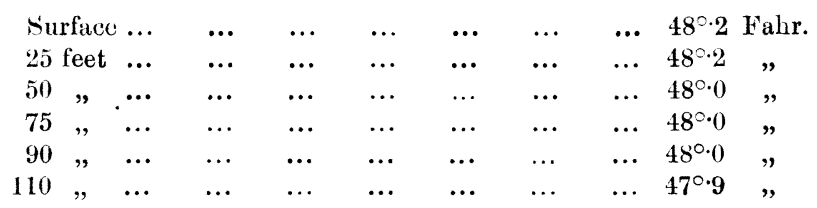

The particulars regarding the lochs dealt with in this paper are collected together in the opposite table for convenience of reference and comparison.

From this table it will be seen that in the thirteen lochs under consideration, which cover an area of $5 \frac{3}{4}$ square miles, about 850 soundings were taken, or an average of 146 soundings per square mile of surface. The aggregate volume of water contained in the lochs is estimated at 11,230 millions of cubic feet, and the area draining into them is over 215 square miles, or thirty-seven times the area of the lochs.

\section{GEOLOGICAL NOTES ON THE LOCHS WITHIN THE BASIN OF THE FARRAR.}

By B. N. PEACH, LL.D., F.R.S., and J. HORNE, LL.D., F.R.S.

THE mapping of the western part of the Beauly basin by the Geological Survey has only been carried southwards to the watershed between Glen Strath Farrar and Glen Cannich, and hence the following notes are confined to the lakes lying within the basin of the Farrar. This area is entirely occupied by the metamorphic rocks of the Highlands, which have been arranged in two divisions : (1) An older series, which has been correlated with the Lewisian or Archæan gneiss of the West Highlands; and (2) a group of crystalline schists, termed the Moine series by the 


\section{BATHYMETRICAL SURVEY OF THE FRESH-WATER LOCHS OF SCOTLAND.}

Geological Survey, which are regarded as altered sediments, and are supposed to rest unconformably on the older Lewisian gneiss.

The members of the older series comprise hornblendic and biotite gneisses, and ultrabasic masses, together with crystalline limestone, graphite schists and eclogites, which resemble the rocks of Lewisian age in the neighbourhood of Glenelg. The Moine series includes two prominent subdivisions: (1) flaggy and massive quartzbiotite-granulites; and (2) muscovite-biotite schists, the latter probably representing an argillaceous phase of sedimentation. In the basin of the Farrar the general strike of the crystalline schists, with the exception of local variations, is northnorth-east and south-south-west, or north-east and south-west-that is to say, obliquely across the course of the main valley.

The basin of the Farrar is traversed by a powerful dislocation, which passes from the Conon valley in a south-west direction by Gleann Chorainn and the head of the river Orrin, thence across Loch Monar to the south-west shoulder of the Riabhachan. It forms a well-marked feature, and is accompanied by much brecciation and staining of the rocks, as may be seen along its course to the north-east of Loch Monar. At certain localities, parallel or branching faults, presumably connected with the main dislocation, are met with, which modify to some extent the surface features.

During the period of confluent glaciers, the ice radiating from the mass of high ground sonth of Loch Monar, embracing Sgurr na Lapaich, 3773 feet, and An Riabhachan, 3696 feet, and from the heights between that lake and Gleann Fhiodhaig to the north, flowed eastwards down Glen Strath Farrar, and streamed northwards through sume of the passes towards the Orrin and Glen Fhiodhaig, and westwards in the direction of the valley of the Ling. At a later stage it escaped only by Strath Farrar. The diverging movement through the various passes is indicated partly by ice-markings, and partly by the disposition of the moraines.

Loch Monar is a true rock basin carved mainly out of the crystalline schists of the Moine series, modified by the movements accompanying the Strath Conon fault and its branches, to which reference has already been made. The lip of the basin is now about half a mile below the present outlet of the lake, the intervening area being silted up by the alluvium brought down by Allt Coire na Faochaigea tributary which joins the main stream opposite Monar Lodge. The rocks forming the barrier of the lake are well seen in the gorge of the Garbh-uisge, where they consist of massive siliceous Moine schists, intensely plicated along vertical axes trending north-east and south-west.

In the narrow part of the lake immediately above Monar Lodge there is a small subsidiary basin, which may be accounted for by inequalities in the hardness of the rocks, and by the irregular distribution of the drift on the west side of the loch. The deep part of the main basin coincides with the belt of crushed strata accompanying the Strath Conon fault that crosses the lake near Lub-an-Inbhir and the parallel dislocation above Creag na h-Iolaire. A third fault, trending east and west, enters the loch at the mouth of Allt nan Uan, which has produced considerable brecciation of the rocks.

The shallow bar near the head of the loch is due to a spit of sand, brought down partly by Allt Riabhachan and partly by the stream at Pait, which has been distributed by the action of the waves. The long stretch of alluvium along Amhainn-an t-Sratha Mhòir indicates that the lake has been silted up for about a mile above its present western limit.

Loch an Tachdaidh and An Gead Loch.-These lochs lie in the bottom of the valley drained by the Garbh-uisge at Pait, which flows into Loch Monar, and are entirely surrounded by drift deposits of the later glaciation. All the small 
projections into these lakes are due to moraine heaps, arranged in such a way as to suggest that they are probably the terminal moraines of a lobe of ice that moved westwards towards the basin of the river Ling.

Loch Calavie lies in one of the passes through which the ice escaped westwards from the Monar area during the period of confluent glaciers. Though immediately surrounded by moraines and peat, it is evidently in part a rock basin, as the rocky barrier formed of muscovite-biotite gneiss appears in the stream not far below the outlet of the lake. The deepest sounding is 84 feet.

Loch Bunacharan and Loch a' Mhuilinn.-T'hese lakes are situated in the valley of the Farrar about midway between Loch Monar and Struy. Their long axes seem to coincide generally with the strike of the crystalline schists. In the case of the former lake, its height above sea-level is 366 feet, its greatest depth 113 feet, and the position of the rocky barrier exposed in the stream about onethird of a mile below the outlet is about 360 feet. The surface level of Loch a' Mhuilinn is 417 feet, and the deepest sounding is 94 feet, and as it discharges over solid rock, it is evidently a small rosk basin. 'There is a high terrace round Loch a' Mhuilinn and on the south side of Loch Bunacharan at a level of 440 feet.

\section{NOTES ON THE BIOLOGY OF THE LOCHS OF THE BEAULY BASIN.}

\section{By JAMES MURRAY.}

THE lochs of Beauly valley were surveyed in late autumn, during very severe weather, unfavourable for the study of biology. 'The lochs in Glen Affric were visited in a time of heavy floods, which raised the lochs several feet while we were working at them. 'Though the tow-nets were used, there was almost nothing got in them. 'The lochs appeared to be flushed and washed out by the spate, or else the animals had gone down to quieter water.

'Throughout the rest of the basin there was great uniformity, the ordinary universal limnetic Crustacea and Rstifers al.one being present, with little call for remark. 'There was an entire absence of all the northern species of Diaptomus, and, although Desmids were fairly abundant in most of the lochs, there were none of the western species.

The few species which only occurred in some of the lochs are noted below. These are also generally distributed in summer, their scarcity in these lochs being due to the late season at which they were visited.

Daphnix.-In all the lochs where Daphnia occurred, it was as the variety yaleata, a large form with the head angled.

Holopedium gibberum.-Ouly in Lochs Calavie and an 'l'achdaidh.

Leptodora kindtii.-Only in Loch Monar.

Polyphemus pediculus.-An Gead loch.

Cyclops strenuus.-Present in most of the lochs. 'The Cyclops in Loch Calavie were red-spotted.

Diaphanosoma brachyu'um.-Found in four lochs-Tachdaidb, Bunacharan, Mullardoch, and Lungard.

Floscularia pelagica.-Loch Monar.

Conochilus.-Both species, C. unicornis (the common lake species) and C. volvox, were present in Loch Monar.

Sponge.-A fresh-water sponge, species not deternined, came up attached to the sounding-rod, from depths of 6 or 8 feet, in Loch a' Mhuilinn. The pieces were long, fing r-shaped. 
BAthymetrical SuRVEY of The Fresh-Water Lochs PLATE I

SIR JOHN MURRAY, K.C.B., F.R.S., D.SC., AND LAURENCE PULLAR,

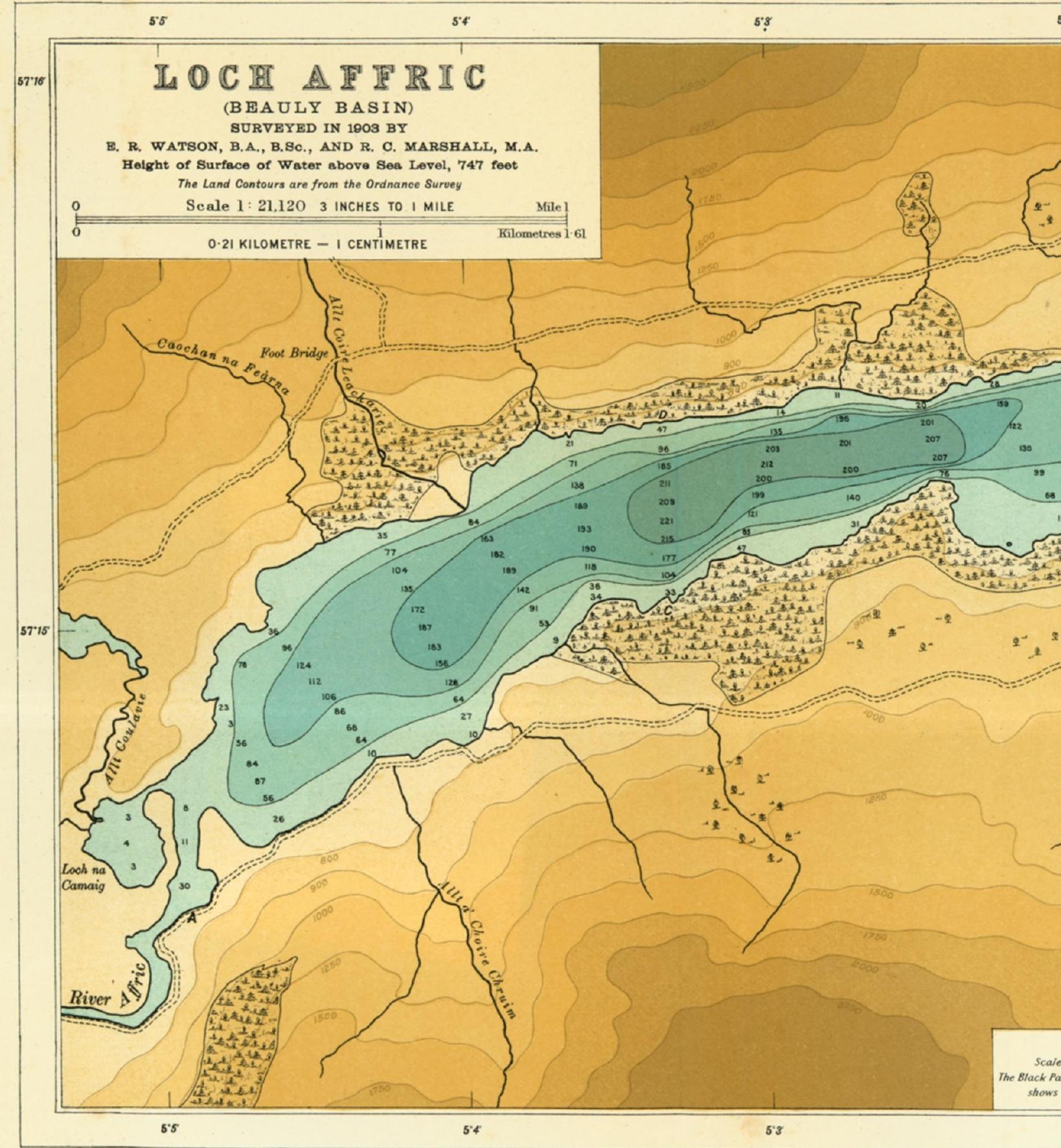

A

LONGITUDINAL SECTION ALONG AXIS OF MAXIMUM DEPTH

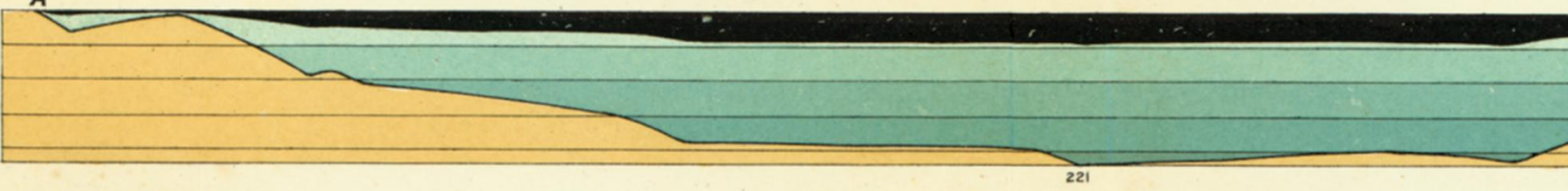




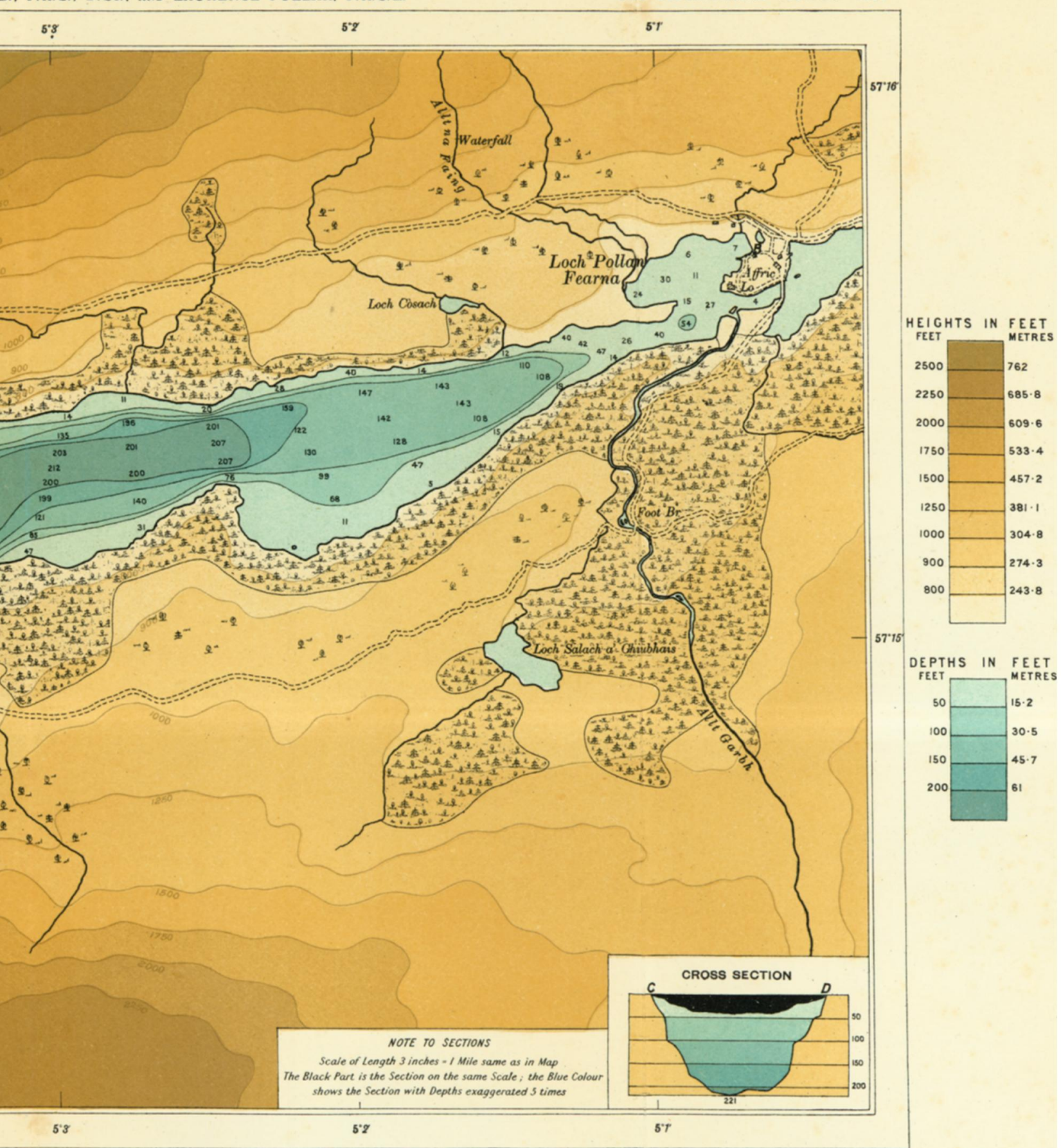



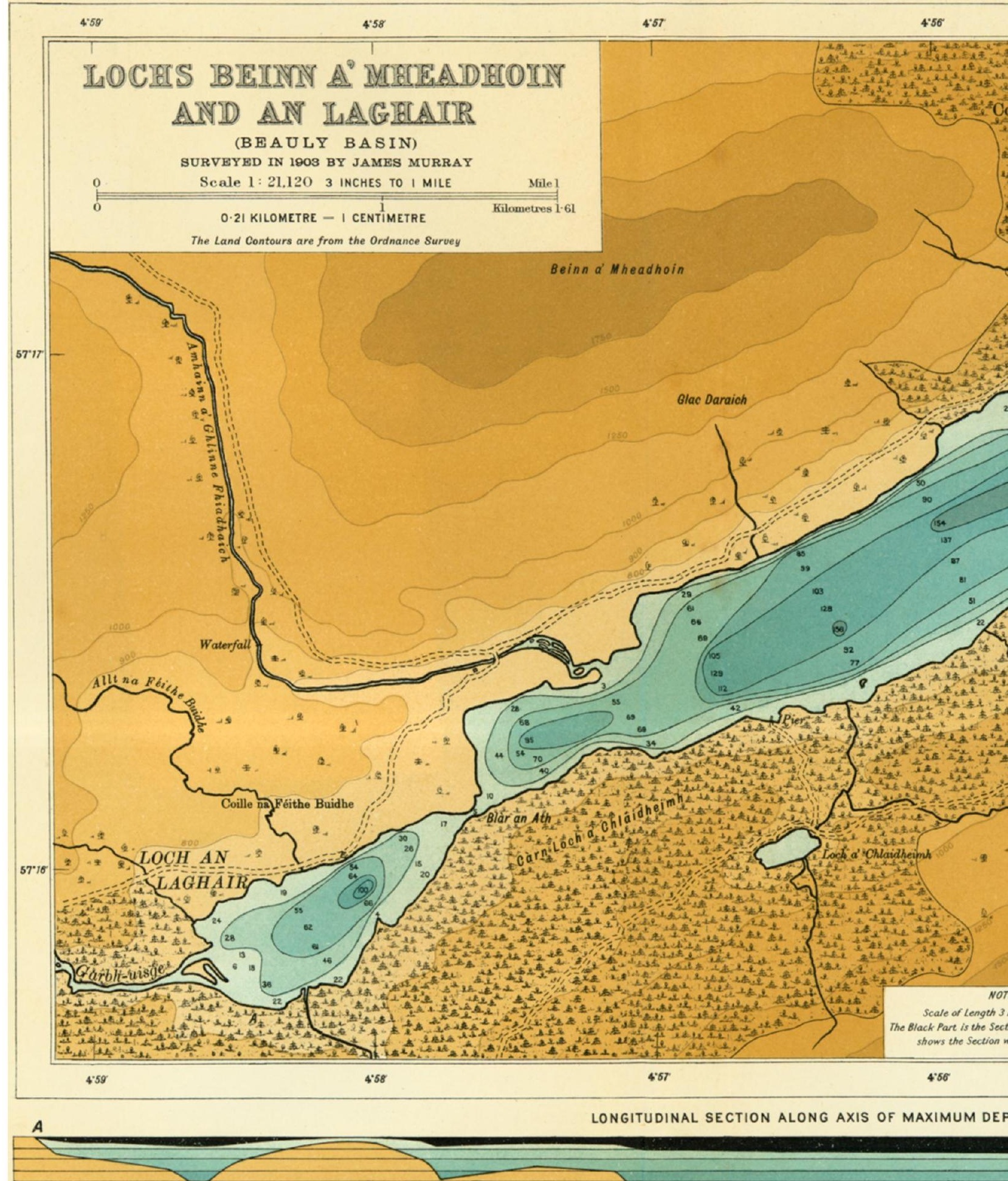


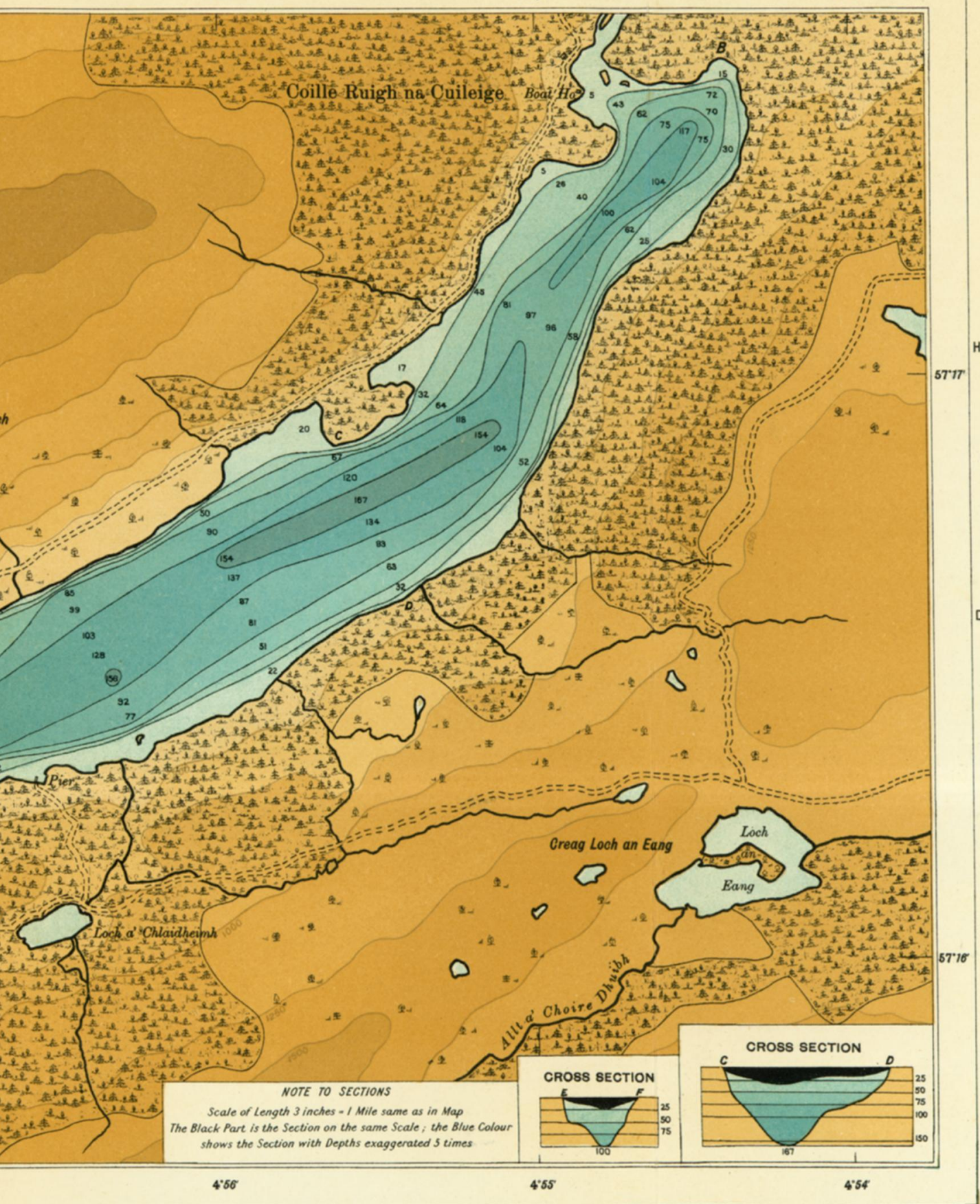




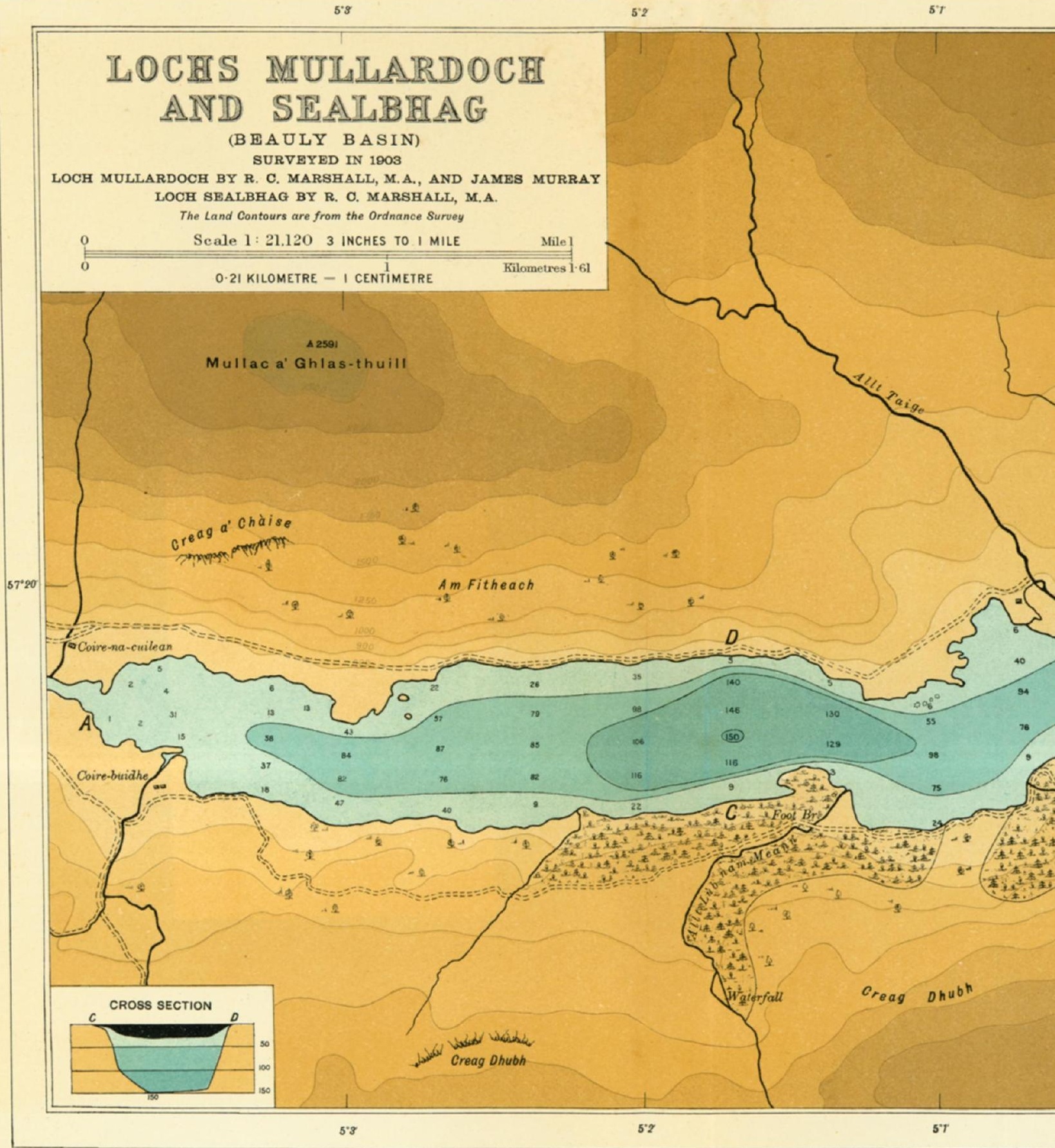


Etrical Suryey of the Fresh-water Lochs of Scotlan I UNDER THE DIRECTION OF

SiR JOHN MURRAY, K.C.B., F.R.S., D.SC., AND LAURENCE PULLAR, F.R.S.E.

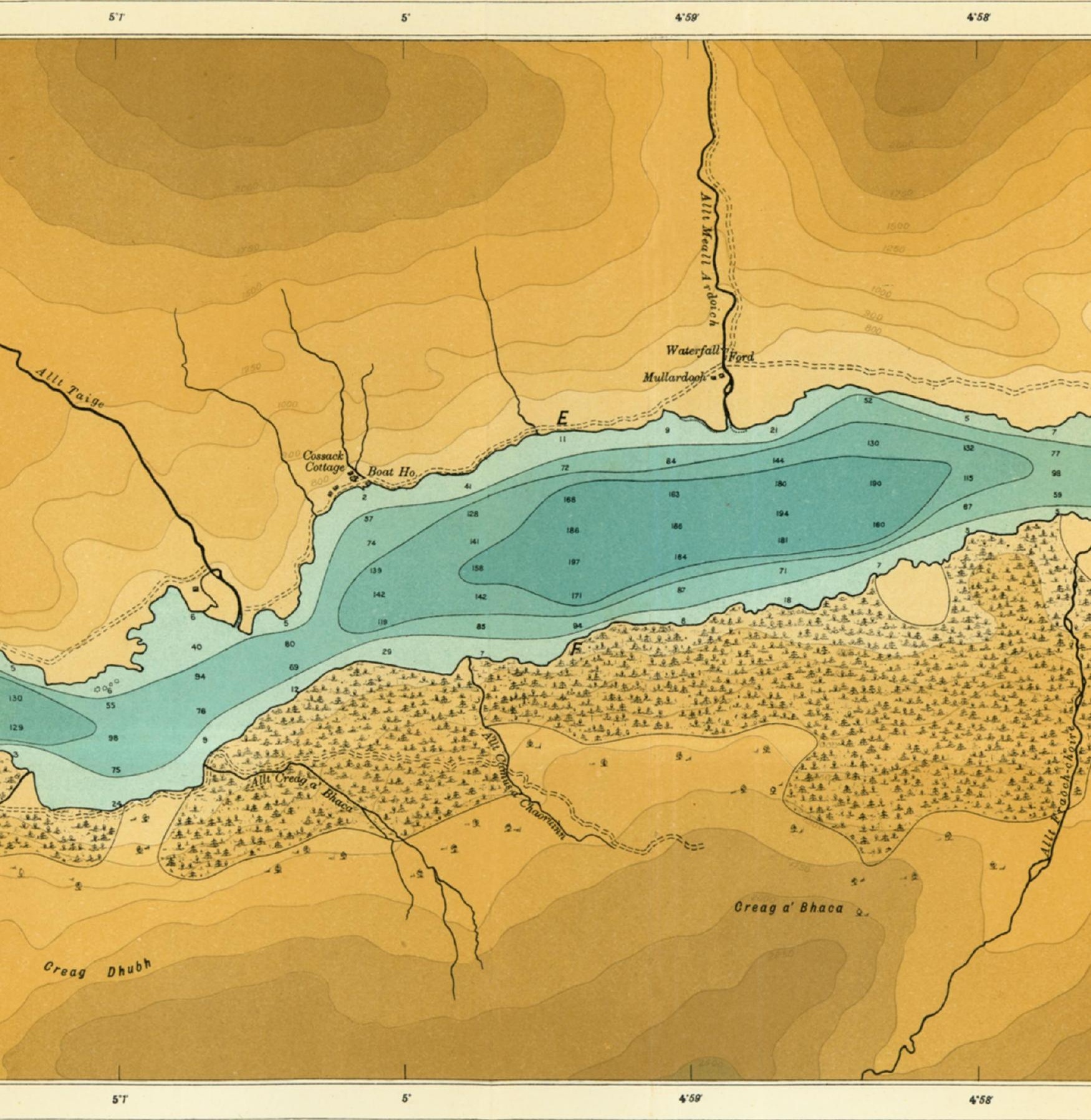

LONGITUDINAL SECTION ALONG AXIS OF MAXIMUM DEPTH 


\section{of SCOTLAND}

THE GEOGRAPHICAL JOURNAL 1906
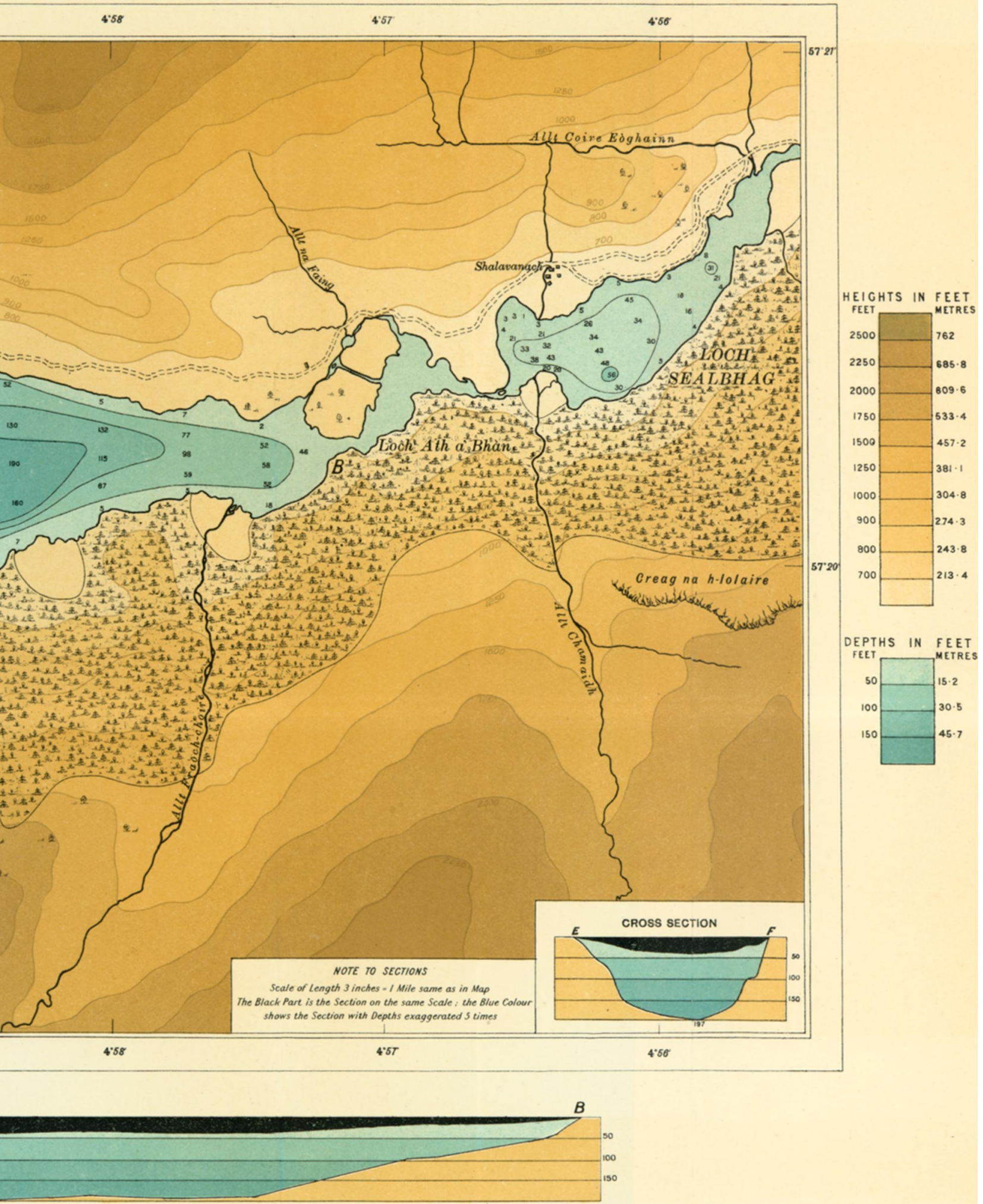


\section{BATHYMETRICAL SUR}

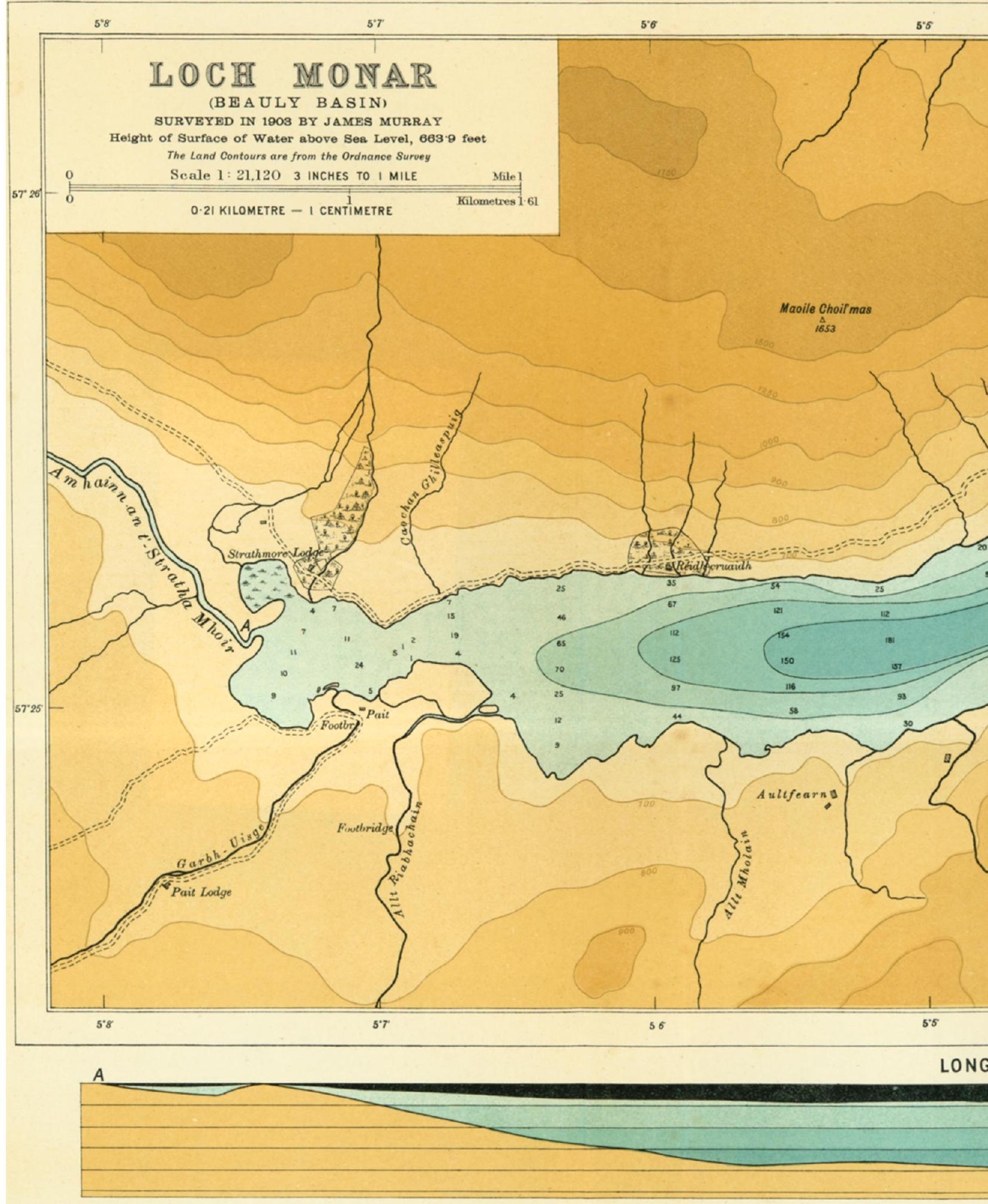


trical Survey of the Fresh-water Lochs of Scotland UNDER THE DIRECTION OF

Sir JOHN MURRAY, K.C.B., F.R.S., D.Sc., AND LAURENCE PULLAR, F.R.S.E.

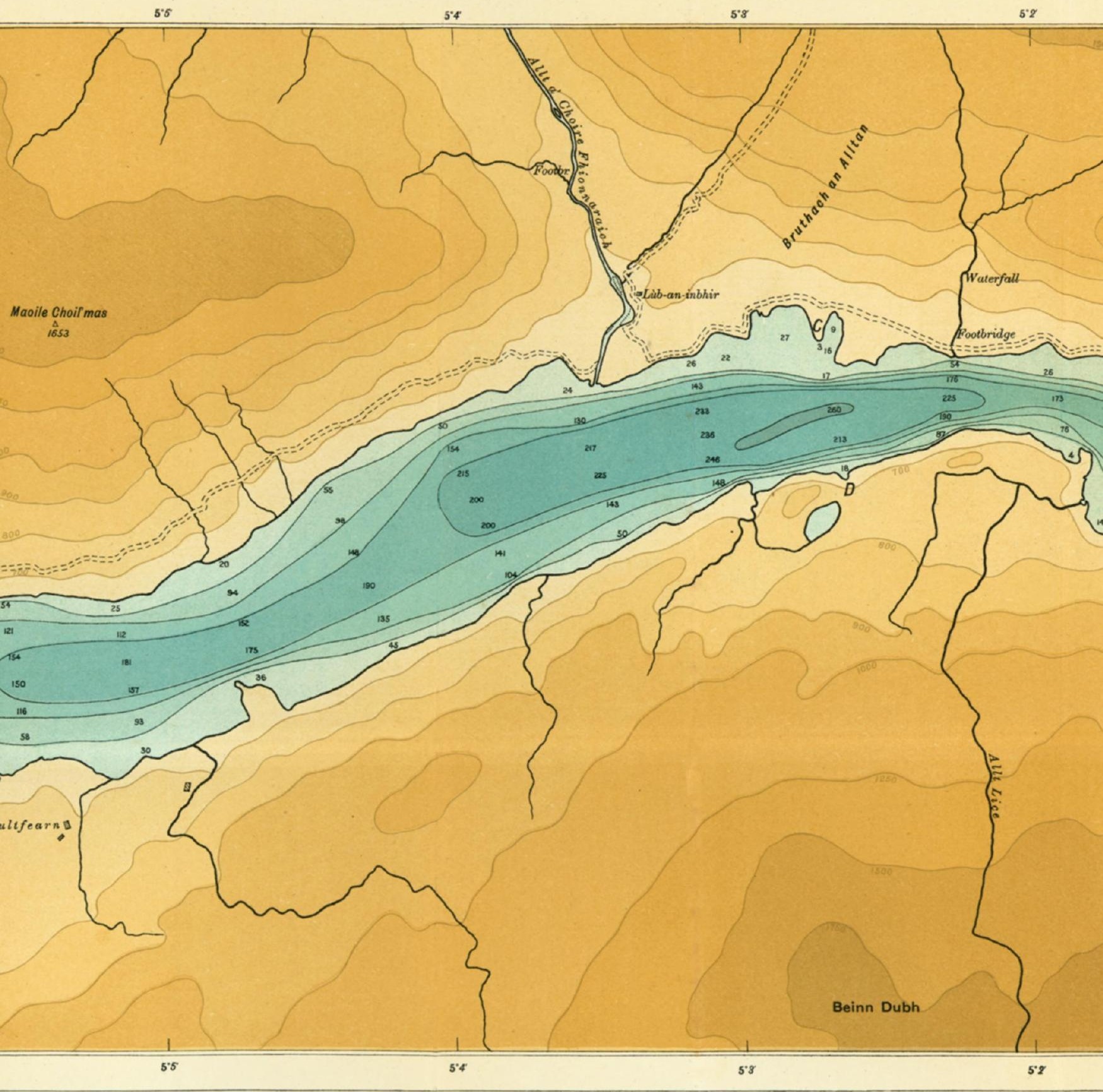

LONGITUDINAL SECTION ALONG AXIS OF MAXIMUM DEPTH 

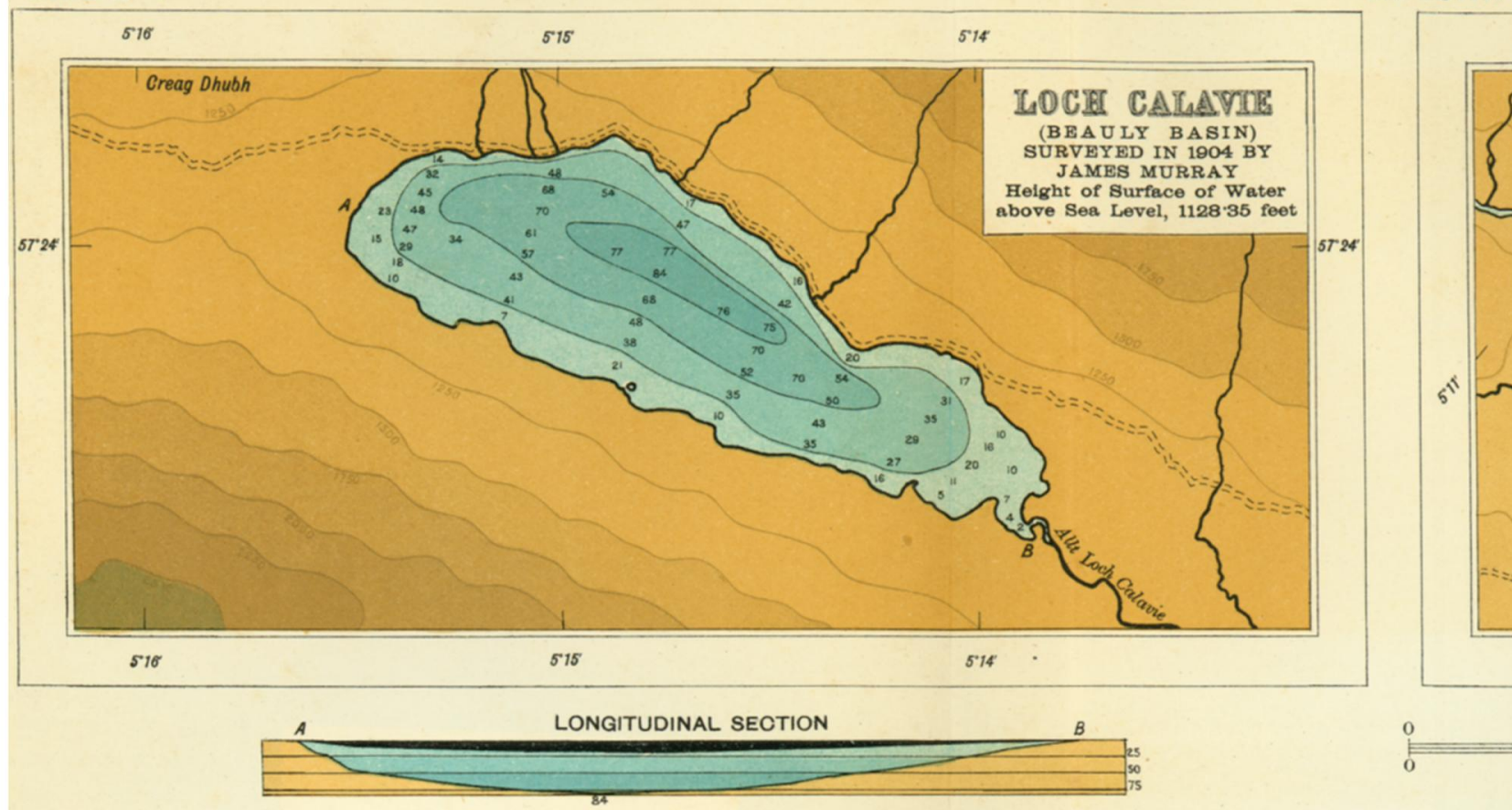

年
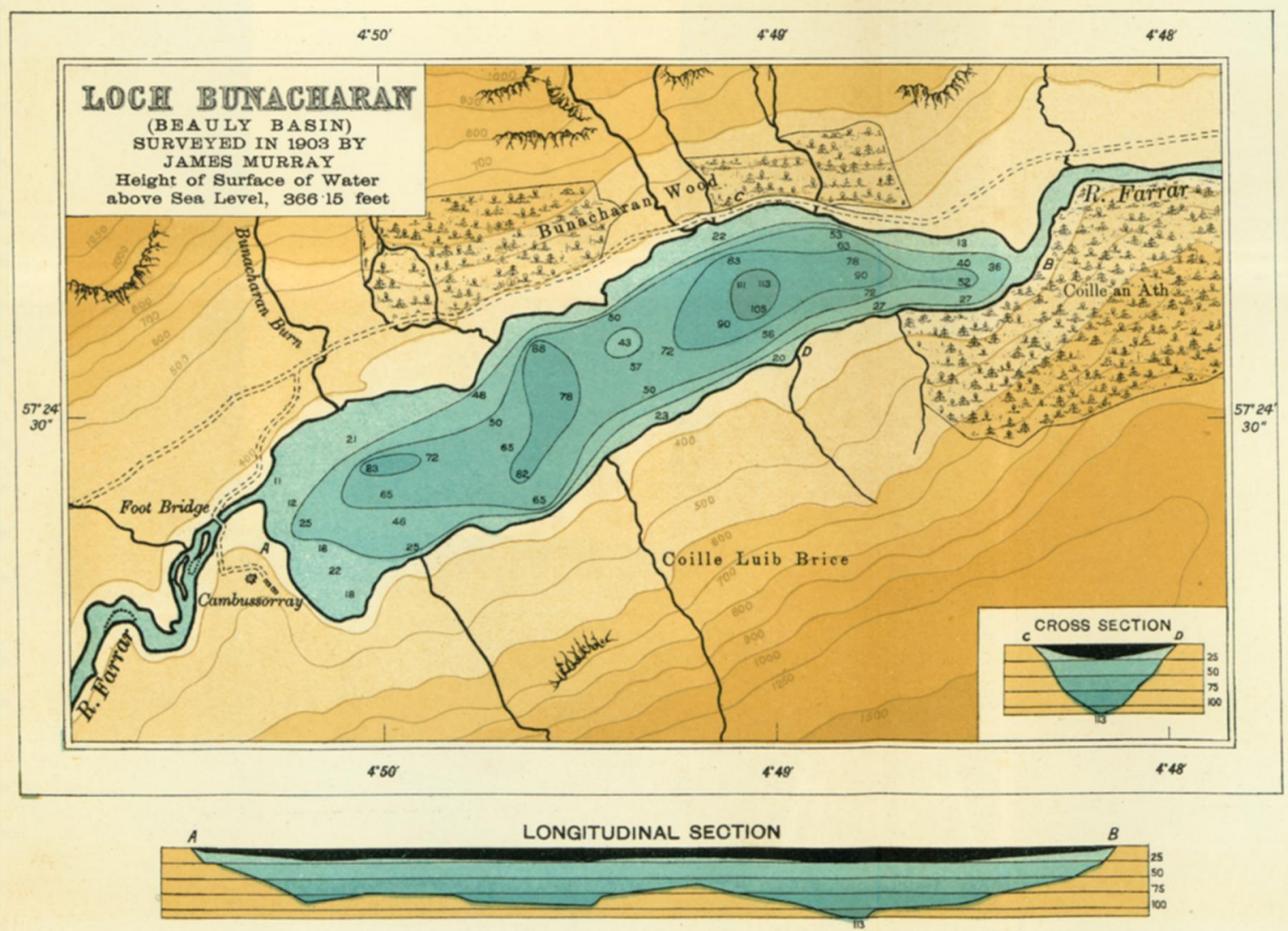

The Edinburgh Geographical Institute

This content downloaded from 131.247.112.3 on Mon, 27 Jun 2016 08:45:18 UTC All use subject to http://about.jstor.org/terms 
etrical Survey of the Fresh-water Lochs of Scotland UNDER THE DIRECTION OF

SiR JOHN MURRAY, K.C.B., F.R.S., D.Sc., AND LAURENCE PULLAR, F.R.S.E.
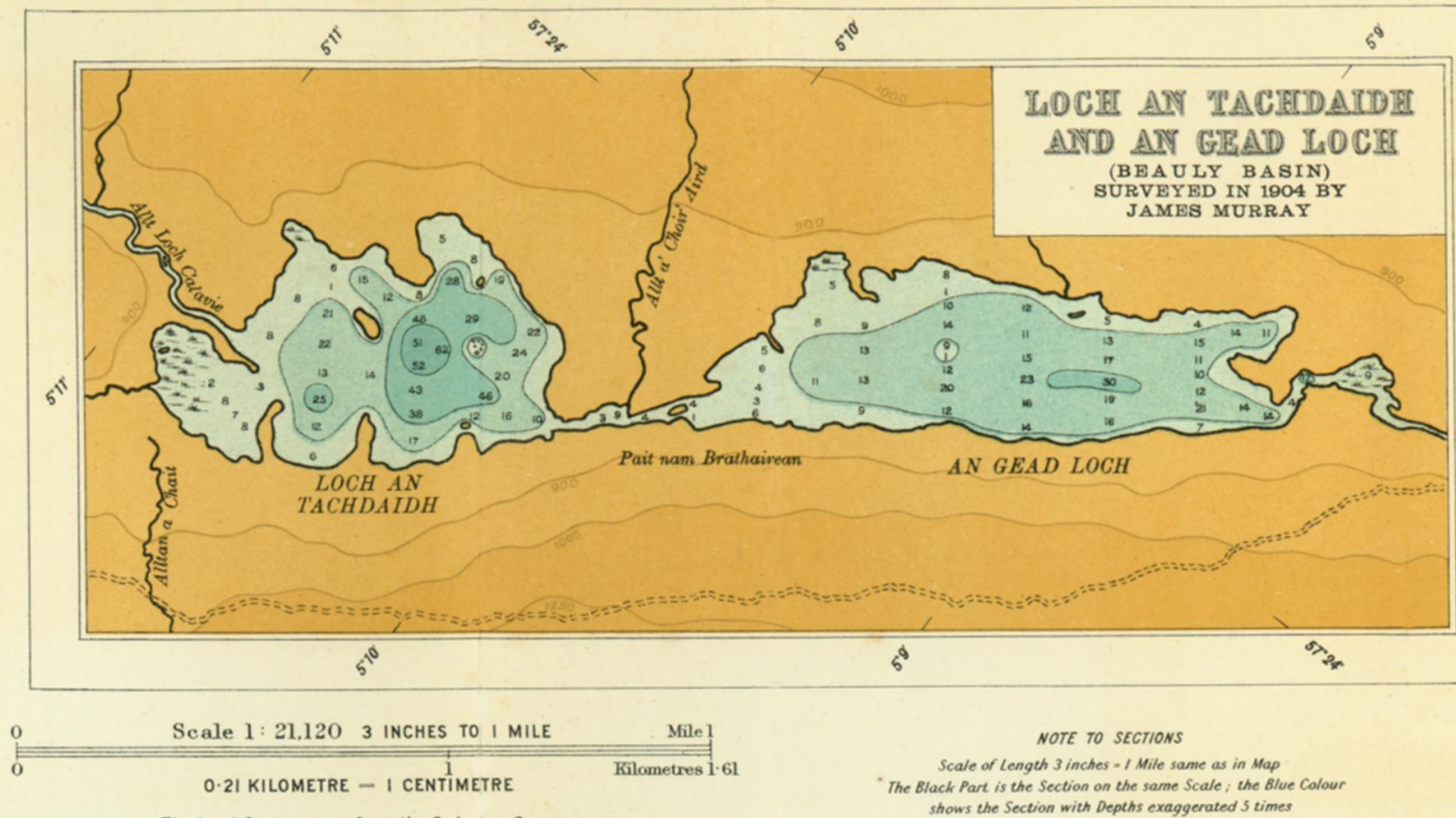

NOTE TO SECTIONS

Scale of Length 3 inches - I Mile same as in Map The Black Part is the Section on the same Scale; the Blue Colour The Land Contours are from the Ordnance Survey shows the Section with Depths exaggerated 5 times
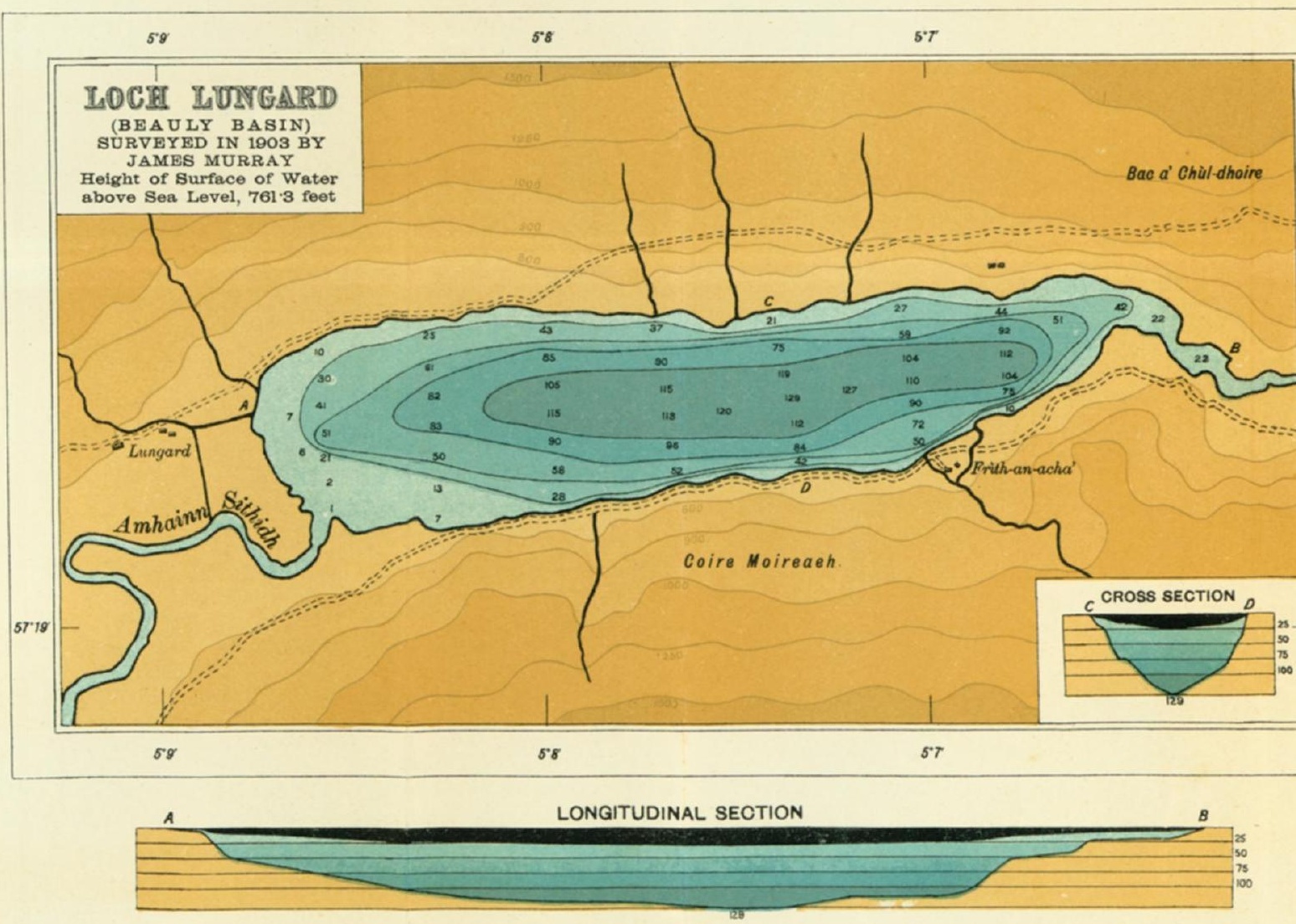

Published by the Royal Geographical Society

This content downloaded from 131.247.112.3 on Mon, 27 Jun 2016 08:45:18 UTC All use subject to http://about.jstor.org/terms 


\section{SCOTLAND}

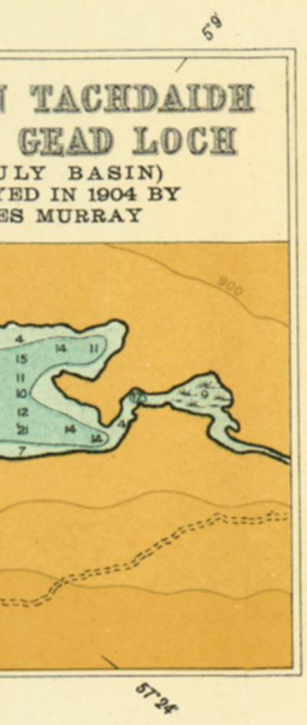

ame as in Map

Scale; the Blue Colour

gerated 5 times

Bac a' Chùl-dhoire

CROSS SECTION
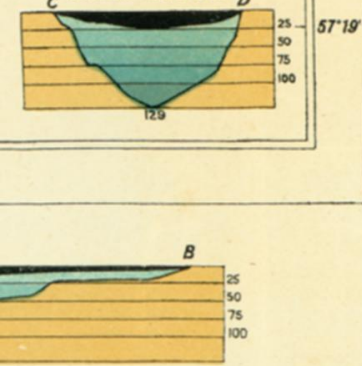

THE GEOGRAPHICAL JOURNAL

1906
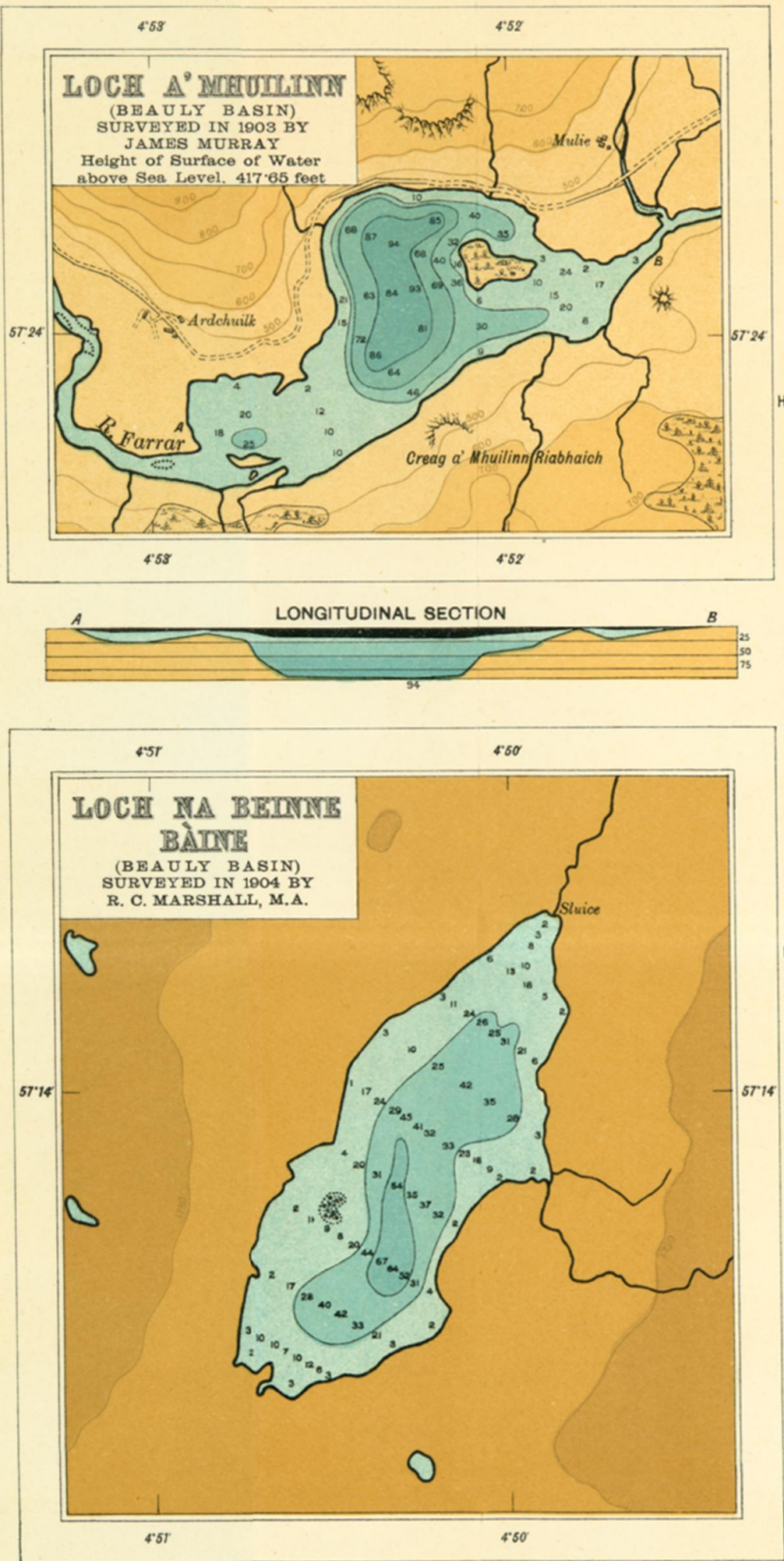

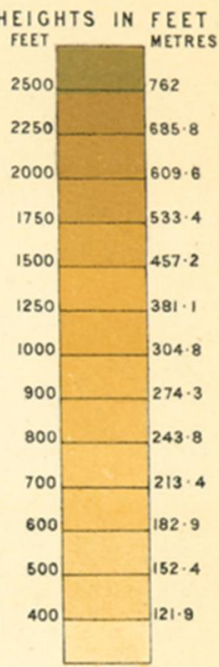

DEPTHS IN FEET FEET METRES

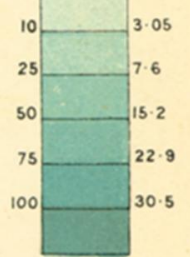

